\title{
Reconstructing the 1867 Keelung Earthquake and Tsunami Based on Historical Documents
}

\author{
Shih-Nan Cheng ${ }^{1, *}$, Chen-Fang Shaw ${ }^{1}$, and Yeong Tein Yeh $^{2}$ \\ ${ }^{1}$ Chien Hsin University of Science and Technology, Taoyuan City, Taiwan, R.O.C. \\ ${ }^{2}$ Department of Resources Engineering, National Cheng Kung University, Tainan, Taiwan, R.O.C.
}

Received 30 August 2015, revised 17 March 2016, accepted 18 March 2016

\begin{abstract}
On 18 December 1867 a disastrous earthquake struck off northern Taiwan and generated a tsunami that caused hundreds of deaths. At that time, with little information available, people could not be expected to identify the mechanism of the 1867 Keelung earthquake or the subsequent tsunami. To reconstruct the earthquake and tsunami available historical documents and references were reviewed and verified. The data were then evaluated for its' credibility. The historical place names were correlated with the present locations and GIS tools were used to reconstruct the earthquake and tsunami and identify the distribution of the resulting damage. Excluding the damage recorded in the Keelung area, there is evidence that shows that the 1867 Keelung earthquake and tsunami killed more than 580 people. The coastal area from Jinshan to Keelung Harbor was the main affected area. With a recorded tsunami wave height of $6 \mathrm{~m}$ occurring in Huanggang and Shueiwei, the run-up height in Jinbaoli Old Street and the Badouzi area is estimated to have been $15 \mathrm{~m}$ high. The tsunami wave height was observed to be $205 \mathrm{~cm}$ at Keelung Harbor Bay. The attenuation law was adopted to simulate the earthquake intensity distribution. The source parameters reasonableness and validity were considered by comparing the earthquake intensity distribution and the resulting damage. Our results show that the 1867 Keelung earthquake was highly correlated with the offshore Shanchiao Fault extension. The length the fault is about $40 \mathrm{~km}$, with the epicenter located at $25.34^{\circ} \mathrm{N}, 121.91^{\circ} \mathrm{E}$ and focal depth of $10 \mathrm{~km}$. The moment magnitude was 7.0.
\end{abstract}

Key words: 1867 Keelung earthquake, Tsunami, Historical document, Shanchiao Fault, Taiwan

Citation: Cheng, S. N., C. F. Shaw, and Y. T. Yeh, 2016: Reconstructing the 1867 Keelung earthquake and tsunami based on historical documents. Terr. Atmos. Ocean. Sci., 27, 431-449, doi: 10.3319/TAO.2016.03.18.01(TEM)

\section{INTRODUCTION}

On 18 December 1867 (lunar calendar 23 November, the sixth year of the Tongzhi), a disastrous earthquake hit northern Taiwan and generated a tsunami that caused hundreds deaths and many houses to collapse. This was the only disastrous tsunamigenic earthquake to occur in Taiwan (Fang 1969; Hsu 1981, 1983b; Tsai 1985; Cheng and Yeh 1989). Of the historical documents compiled by Fang (1969) and Hsu (1983a), most are literal descriptions of the resulting tsunami damage rather than records of the event distribution and characteristics. No quantitative report of the tsunami's impact is given in the documents. Hsu (1983b) and Tsai (1985) used data from the same limited source, but estimated different epicenter locations. Hsu (1983b) calcu-

\footnotetext{
* Corresponding author

E-mail:snan@uch.edu.tw
}

lated that the epicenter was offshore of Keelung $\left(25.2^{\circ} \mathrm{N}\right.$, $121.8^{\circ} \mathrm{E}, \mathrm{M}=7.0$ ), and Tsai (1985) inferred that the epicenter was offshore of Jinshan $\left(25.3^{\circ} \mathrm{N}, 121.7^{\circ} \mathrm{E}, \mathrm{M}=7.0\right)$. Xie and Cai (1987) and Hsu and Li (1996) compiled information from sources in China, but most of the documents are translated from earlier sources or are paraphrased reports of the event and provide insufficient information to assess the validity of original documents. Some of these documents contain inconsistencies. With the limited information left by antiquity, opinions concerning the mechanism of the earthquake and subsequent tsunami can be divided into four major groups: (1) Tang (1971) and Yang et al. (1983) considered that a submarine volcanic eruption located around $134 \mathrm{~km}$ northeast of Keelung Harbor $\left(26.183^{\circ} \mathrm{N}, 122.458^{\circ} \mathrm{E}\right)$ was the primary cause of the tsunami; (2) Hsu (1983b) and Tsai (1985) had different views on the epicenter location, 
but agreed that the tsunami was caused by an earthquake and a fault; (3) Ma and Lee (1997), however, believed that the tsunami was the result of an earthquake, a landslide, a volcanic eruption, and coastal landform; and (4) Wu (2013) thought that an underwater landslide triggered by an earthquake was the cause of the tsunami. These different interpretations generate considerable bewilderment about the facts of the 1867 Keelung earthquake and tsunami.

In recent years, easy Internet access and the digitalization services provided by most libraries have brought some neglected historical documents and materials to light. This provides the opportunity to re-examine the 1867 Keelung earthquake and tsunami. Therefore, this study begins with a review of the historical documents and references. It uses the original documents to attach importance to the validity of the information and avoid misunderstandings from interpreting paraphrased documents and translation between languages. A database is to be established to store these original documents and archives to provide references for follow-up studies. The data will be evaluated and compared for their credibility in terms of reconstructing the damage distribution, the correlated intensity and assessing the tsunami wave height and run-up height. The relevant geological and geophysical data are referred to in order to identify the possible source parameters. The attenuation law was applied to simulate the isoseismic map. The reasonableness and validity of the source parameters can be determined by correlating the isoseismic map with the disaster distribution.

\section{HISTORICAL DOCUMENTS RELATED TO THE EVENT}

At present, the historical documents that refer to the 1867 Keelung earthquake and tsunami are contained in Fang's (1969) and Hsu's (1983a) collections: (1) Chen's (1871) History of the Tamsui Prefecture (in Chinese); (2) Shen's (1893) History of the Miaoli Prefecture (in Chinese); (3) Dainippon Dictionary of Place Name Sequel [original in Japanese, only Chinese version available. The author was inscribed as Yoshida (1909) by Fang (1969) but was recorded as Ino (1909) by Hsu (1983a)]; (4) Mackay's (1896) From Far Formosa (original in English, only Chinese version available); (5) Alvarez's (1915) Descripcion geografica de la isla de Formosa (original in Spanish, only Chinese version available). Based on the previous records, the earthquake hit on 18 December 1867. The date of the event was given without an accurate time for the occurrence. Hundreds of people were killed and many houses were destroyed. Landslides occurred and the ground cracked along the coast of Keelung and Jinbaoli. The sea rose violently. Damage was concentrated in the Keelung area. There are detailed descriptions of the tsunami in Keelung Harbor: "Water in the harbor seemingly receded to the bottom. Ships were caught on the beach. Shortly afterwards, the water returned with violent intensity.
The ships were washed away. Fish on the beach were gone too. Everything on the beach was washed away. Well-built houses were struck and destroyed. Land was buried under sand." Rice fields dropped three feet suddenly in Jinbaoli. Sulfurous water spouted upward to a height of forty feet. More than half of the town of Shilin was destroyed. These are mostly fragments and partial descriptions of the event. Quantitative data of the damage are not available.

In Xie and Cai's (1987) Compilation of Historical Earthquake Data in China (in Chinese), four documents about the 1867 Keelung earthquake were added: (1) Cheng and Chen's (1927) Annals of Xiangshan County (in Chinese); (2) Musha's (1951) Japan Earthquake Historical Records (original in Japanese, only Chinese version available); (3) The North China Daily News of 4 January 1868 (original in English, only Chinese version available); (4) Hancock's (1882) Tamsui Trade Report, for the year 1881 (original in English, only Chinese version available). Among these, The North China Daily News gave a detailed and quantitative description of the damage in the Tamsui area, but only qualitative reports of the tsunami in Keelung Harbor. According to the descriptions in the document, the author may have been present in Tamsui when the earthquake occurred. It is clearly stated that the earthquake struck Tamsui at 10:20 am, but hit Keelung at 09:45 am. The writer explained that the time difference for the quake between Keelung and Tamsui was due to the fact that "Often one person's watch is half an hour faster or slower than another's". The damage in Tamsui was only found on high ground. Houses fell regularly from the northeast toward the southwest, with thirty people killed. Pa-Qian- $\mathrm{Na}$ (Chinese transliteration), a small town a few miles away from Tamsui, suffered more, and about 150 persons died. There were no sea or river anomalies mentioned in this document. At Keelung the first shock lasted for thirty seconds. The ground cracked in front of the Keelung Custom House. Most of the houses in the town collapsed. The water in the harbor rushed out and left it dry as far as Yan-Wang-Yan (a Chinese transliteration which means "Hades stone" in Chinese) for some seconds. The sea then returned in two huge waves, swamping sampans and drowning the people in them. Junks were carried away and stranded high and dry opposite Keelung. Big rocks slid from nearby hills and sulfur pits. According to the residents, a huge crack opened in the ground and stretched out to the coast. Many place names have been mixed up due to the lack of original documents and only Chinese editions can be found. The depiction of the damage in Keelung Harbor in the Tamsui Trade Report for the year 1881 is similar to that given in The North China Daily News, which has more descriptions of the inundation and ruins in Keelung, Jinbaoli and $\mathrm{Ba}-\mathrm{Qi}-\mathrm{Na}$ (Chinese transliteration). Musha (1951) described significant volcanic activity in the Japan Earthquake Historical Records: "A big earthquake hit Keelung, the whole city had been devastated. Tsunami occurred. Many 
were dead. Lava overflowed from the nearby caldera."

In addition to the collections of Fang (1969) and Hsu (1983a), Hsu and Li (1996) found more documents related to the event which include three research reports from China and one report from the United Daily News (25 May 1960). (1) Li (1981) referred to the Japan Earthquake Historical Records: "On 23 November, the sixth year of Tongzhi, a big earthquake hit Keelung, Taiwan. Houses collapsed and it came along with a tsunami. Volcanic pits emitted hot water. Many people died." This information was quoted by Musha (1951). However, in Xie and Cai's (1987) document (Chinese version), it was described as "Lava overflowed from the nearby caldera". Clearly, a translation error has been made.

(2) Bao et al. (1991) referred to Ms. Ye's description: "The tsunami lingered for 38 hours, $120 \mathrm{~km}$ of the coastline were flooded and 40,000 to 50,000 people were killed." This information matches the description which Soloviev and Go (1974) collected about the 1782 tsunami event.

(3) Li referred to Soloviev and Go (1974), "The surface of the Yangtze estuary dropped by $135 \mathrm{~cm}$, then had a runup of $165 \mathrm{~cm}$. It was surely deemed as a tsunami."

(4) An interview was held with Tang, the director of the Weather Forecast Station, Taiwan Weather Bureau, after a Chilean tsunami was triggered by an earthquake there in 1960; "According to Takahashi's research, a tsunami had happened in Taiwan in the twelfth year of Guangxu. The maximum height of the tsunami was $7.5 \mathrm{~m}$ and it caused a great deal of damage to Keelung. From the records of Oka, on 18 December, the twelfth year of Guangxu, a tsunami was triggered by an earthquake in Keelung. The tsunami destroyed numerous houses and drowned hundreds of people along the coastal villages of Tamsui, Keelung-tou and Jinbaoli." Hsu and Li (1996) believed that the twelfth year of Guangxu should be the year 1867, the maximum height of the 1867 Keelung tsunami was $7.5 \mathrm{~m}$ and the tsunami destroyed houses in the Tamsui area. Significant differences can be found between Hsu and Li's observations and the report in The North China Daily News.

The information given above indicates that the Keelung area was the most severely damaged, followed by the Shilin and Tamsui areas. The tsunami was more noteworthy in Keelung Harbor. However, the overall information obtained is somewhat disorganized. In addition, some of the content and partial descriptions contain inconsistencies. There is therefore a need to collect, classify, and understand the mechanism of the 1867 earthquake and subsequent tsunami.

In recent years, the digitization of ancient texts, historical and cultural documents has become prevalent in libraries and research institutes and offers access for inquiry and reading through the Internet, allowing neglected historical documents and data to be explored. For example, Cheng (2014a, b) found an English report of the 1867 Keelung earthquake and tsunami in The North China Herald and Market Report (of 8 January 1868) in which the content is the same as that in The North China Daily News (of 4 January 1868) [Xie and Cai's (1987) translation in Chinese]. The North China Daily News had no related documents for that time period. The two newspapers were also under the same ownership. We can deduce that either the two newspapers both reported the event, or there was a mistake made such as an incorrect quotation or a clerical error. Another important document that was found is Okamoto's (1913) Terrain Changes Around Kim-pau-li during Tongzhi Years (in Japanese) which gives a thorough description of the damage caused by the earthquake and tsunami in the Jinbaoli region, where the streets were more harshly hit than in the Keelung area. There are exact digital descriptions of the heights of the tsunami waves at Huanggang and Suiwei. It is believed that there are still many documents and manuscripts to be discovered. This study will continue to explore the validity of the historical documents and reconstruct the damage distribution from the 1867 earthquake and the tsunami impact by collating and analyzing all of the available data, and furthermore, consider the validity of the source parameters.

\section{METHODOLOGY}

The methods applied to reconstruct the 1867 Keelung earthquake and tsunami are shown in (Fig. 1).

\subsection{Collection and Collation of Historical Documents}

This study began by collecting and classifying historical documents that cover Taiwan and nearby areas in the Chinese, English, Japanese, French, Spanish, and Russian languages. In sorting these materials raw data were taken in consideration of the original source in order to avoid any deviation that might have occurred in translating or quoting. Any document that is unable to provide its original source is marked with an asterisk $(*)$ and given a reference in the 'Reference' column (Tables 1 and 2). In reference to the current writer, Cheng (2014a), the historical documents and archives are divided into four categories: (1) the official version of the record; (2) the local version from the literature; (3) personal records and articles; and (4) temple establishment history and epigraphy. When an inconsistency occurs with regard to the same earthquake event, the official version will be considered as the first priority, then the local version and then the next, in the following order:

\section{(1) Official version of the file}

The major documents include official memorials, letters to the throne and relevant files that contain statistics of the disaster situation, distress relief among the disaster victims and disaster recovery plans. However, at the time this earthquake occurred the Qing Dynasty was fighting the Taiping Rebellion. Most of the letters to the throne and official records focused on the war. Official files related to 


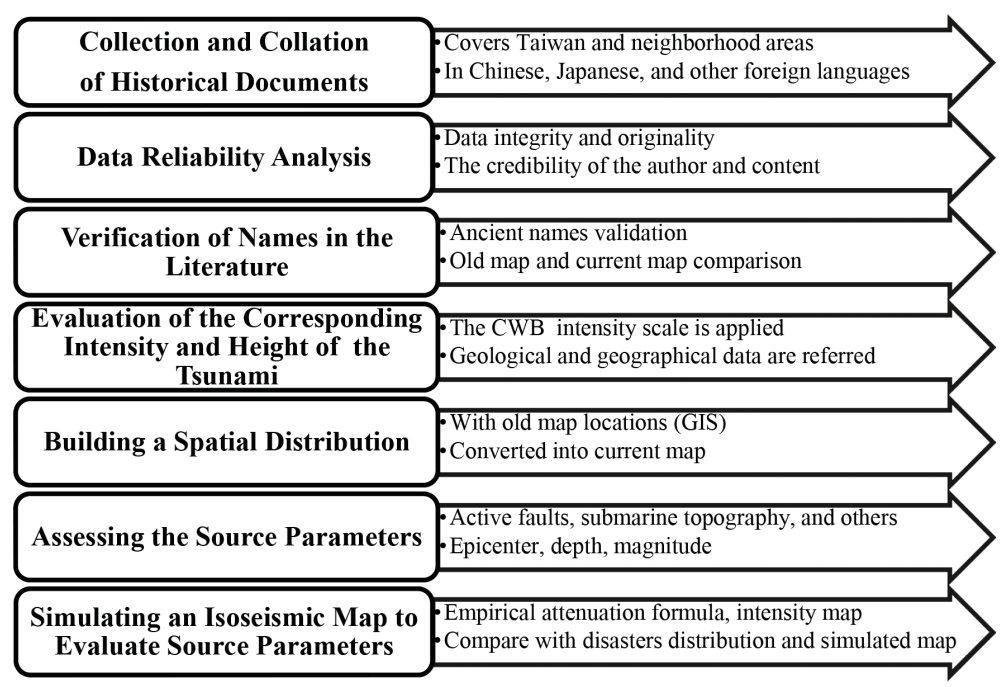

Fig. 1. Methods of data processing.

Table 1. Local versions of the literature on the 1867 Keelung Earthquake.

\begin{tabular}{|c|c|c|}
\hline No. & Original document & Reference \\
\hline 201 & North China Daily News/ Dec. 19, 1867* & Xie and Cai (1987) \\
\hline 202 & North China Daily News/ Dec. 20, $1867^{*}$ & Xie and Cai (1987) \\
\hline 203 & New Orleans Times/ Dec. $21,1867^{*}$ & Perrey (1872) \\
\hline 204 & North China Daily News/ Dec. 27, 1867* & Xie and Cai (1987) \\
\hline 205 & North China Daily News/ Jan. 4, 1868* & Xie and Cai (1987) \\
\hline 206 & The North China Herald and Market Report/ Jan. 8, 1868 & \\
\hline 207 & $\begin{array}{l}\text { Chen (1871) History of the Tamsui Prefecture. (in Chinese) } \\
\text { 陳培桂 (1871) 淡水廳志 }\end{array}$ & \\
\hline 208 & Hancock (1882) Tamsui Trade Report, for the year 1881. & \\
\hline 209 & $\begin{array}{l}\text { Shen (1893) History of the Mioli Prefecture. (in Chinese) } \\
\text { 沈茂蔭 (1893) 苗栗縣志 }\end{array}$ & \\
\hline 210 & $\begin{array}{l}\text { Murakami (1899) Taiwan Bulletin. (in Japanese) } \\
\text { 村上玉吉 (1899) 臺灣紀要 }\end{array}$ & \\
\hline 211 & $\begin{array}{l}\text { Cai (1917) Annals of Shuang-Lin Town.* } \\
\text { 蔡蒙 (1917) 雙林鎮志 }\end{array}$ & Xie and Cai (1987) \\
\hline 212 & $\begin{array}{l}\text { Lian (1918) Taiwan T'ung Shih (General History of Taiwan). (in Chinese) } \\
\text { 連横 (1918) 臺灣通史 }\end{array}$ & \\
\hline 213 & $\begin{array}{l}\text { Cheng and Chen (1927) Annals of Xiangshan County.* } \\
\text { 鄭邁和陳漢章 (1927) 象山縣志 }\end{array}$ & Xie and Cai (1987) \\
\hline 214 & $\begin{array}{l}\text { Jane (1931) Chronicles of Keelung. (in Japanese) } \\
\text { 簡萬火 (1931) 基隆誌 }\end{array}$ & \\
\hline 215 & $\begin{array}{l}\text { Wang (1972) Chronicles of Taichung City. (in Chinese) } \\
\text { 王建竹 (1972) 臺中市志 }\end{array}$ & \\
\hline 216 & $\begin{array}{l}\text { Historical Research Committee of Taiwan Province (1984) Re-edition Common History of Taiwan. (in Chinese) } \\
\text { 臺灣省文獻委員會 (1994) 重修臺灣省通志 }\end{array}$ & \\
\hline 217 & $\begin{array}{l}\text { Lin et al.(1988) Chronicles of Taichung County. (in Chinese) } \\
\text { 林世珍等人 (1989) 臺中縣志 }\end{array}$ & \\
\hline 218 & $\begin{array}{l}\text { Taipei Government (1989) Chronicles of Taipei City. (in Chinese) } \\
\text { 臺北市政府 (1998) 臺北市志 }\end{array}$ & \\
\hline 219 & $\begin{array}{l}\text { Cheng (2005) Annals of Sanchong Sequel. (in Chinese) } \\
\text { 鄭懿瀛 (2005) 三重市志續編 }\end{array}$ & \\
\hline 220 & $\begin{array}{l}\text { Chen (2006) Re-edition Annals of Miaoli County. (in Chinese) } \\
\text { 陳運棟總編纂 (2006) 重修苗栗縣志 }\end{array}$ & \\
\hline
\end{tabular}

Note: * refers to files which lack the original document. 
Table 2. Personal records and articles about the 1867 Keelung Earthquake.

\begin{tabular}{|c|c|c|}
\hline No. & Original document & Reference \\
\hline 301 & Holt (1868) Report of Recent Earthquakes in Northern Formosa. & \\
\hline 302 & $\begin{array}{l}\text { Perrey (1872) Note Sur Les Tremblements de Terre en } 1868 \text { Avec Suppléments Pour les Années Antérieures de } 1843 \text { à } 1867 . \\
\text { (in French) }\end{array}$ & \\
\hline 303 & Perrey (1873) Suppléments Aux Notes Sur Les Tremblements de Terre Ressentis de 1843 à 1868. (in French) & \\
\hline 304 & Dodd (1888) Journal of a Blockaded Resident in North Formosa During the Franco-Chinese War: 1884-5. & \\
\hline 305 & Mackay (1895) From Far Formosa. & \\
\hline 306 & $\begin{array}{c}\text { Taihoku Meteorological Observatory (1899). Taiwan Meteorological Report, No. 1. (in Japanese) } \\
\text { 臺北測候所 (1899) 臺灣氣象報學文第一 }\end{array}$ & \\
\hline 307 & Davidson (1903) The Island of Formosa, Past and Present. & \\
\hline 308 & $\begin{array}{c}\text { Omori (1906) Investigation of Taiwan Earthquake. (in Japanese) } \\
\text { 大森房吉 }(1906) \text { 臺灣地震調查一斑 }\end{array}$ & \\
\hline 309 & $\begin{array}{l}\text { Taiwan Governor-General Office of Civil Affairs (1907) Report of Earthquake Damages of Chiayi. (in Japanese) } \\
\text { 台灣總督府民政部總務局 (1907) 嘉義地方震災誌 }\end{array}$ & \\
\hline 310 & Omori (1907) Preliminary Note on the Formosa Earthquake of March 17, 1906. & \\
\hline 311 & $\begin{array}{c}\text { Yoshida (1909) Dainippon Dictionary of Place Name Sequel. (in Japanese) } \\
\text { 吉田東伍 (1909) 大日本地名詞書續編 }\end{array}$ & \\
\hline 312 & $\begin{array}{l}\text { Yoshida (1923) Dainippon Dictionary of Place Name, Volume VI. (in Japanese) } \\
\text { 吉田東伍 (1923) 大日本地名辭書第六卷北海道・樺太・琉球・臺灣 }\end{array}$ & \\
\hline 313 & $\begin{array}{l}\text { Yoshida (1970) Dainippon Dictionary of Place Name, Enlarged Edition. (in Japanese) } \\
\text { 吉田東伍 (1970) 增補大日本地名辭書-北海道・樺太・琉球・臺灣 }\end{array}$ & \\
\hline 314 & $\begin{array}{c}\text { Ino (1909) Dainippon Dictionary of Place Name Sequel.* } \\
\text { 伊能嘉矩 }(1909) \text { 大日本地名辭書續編 } \\
\end{array}$ & Hsu (1983a) \\
\hline 315 & $\begin{array}{c}\text { Taiwan Governor Production Bureau of Civil Affairs (1912) Report of Geological Survey about Datun Volcano. (in Japanese) } \\
\text { 臺灣總督府民政部殖產局 (1912) 大屯火山彙地質調查報文 }\end{array}$ & \\
\hline 316 & Milne (1912) A Catalogue of Destructive Earthquakes A.D. 7 to A.D. 1899. & \\
\hline 317 & $\begin{array}{c}\text { Okamoto (1913) Terrain Changes Around Kim-pau-li during Tongzhi Years. (in Japanese) } \\
\text { 岡本要八郎 (1913) 同治年間に於ける金包里附近の地變 }\end{array}$ & \\
\hline 318 & Taihoku Meteorological Observatory (1914) The Climate, Typhoons, and Earthquakes of the Island of Formosa (Taiwan). & \\
\hline 319 & Alvarez (1915) Descripcion Geografica de la Isla de Formosa. (in Spanish) & \\
\hline 320 & $\begin{array}{c}\text { Omori (1919) Japan Big Earthquake Overview Table. (in Japanese) } \\
\text { 大森房吉 (1919) 本邦大地震概要 }\end{array}$ & \\
\hline 321 & $\begin{array}{c}\text { Xu (1933) A Collection of Xu Nan Ying. (in Chinese) } \\
\text { 許南英 (1933) 窺園留草/觀原先生自訂年譜 }\end{array}$ & \\
\hline 322 & $\begin{array}{l}\text { Oyama (1934) Taiwan Earthquake and Intensity. (in Japanese) } \\
\text { 大山勇傳 (1934) 臺灣島の地震及其震度 }\end{array}$ & \\
\hline 323 & $\begin{array}{l}\text { Nishimura (1936) The History of Taiwan Earthquake. (in Japanese) } \\
\text { 西村傳三 (1936) 臺灣地震史 }\end{array}$ & \\
\hline 324 & $\begin{array}{c}\text { Miyabe (1936) Recent Seismic Activity in Taiwan. (in Japanese) } \\
\text { 宮部直巳 (1936) 臺湾に於ける最近の地震活動 }\end{array}$ & \\
\hline 325 & $\begin{array}{c}\text { Abe (1938) The Study of Local Name in Taiwan. (in Japanese) } \\
\text { 安倍明義 (1938) 臺灣地名研究 } \\
\end{array}$ & \\
\hline 326 & Heck (1947) List of Seismic Sea Waves. & \\
\hline 327 & $\begin{array}{c}\text { Oka (1948) A Complete Collection of Taiwan Meteorological Data, Earthquake. (in Chinese) } \\
\text { 岡四四亥 (1948) 臺灣氣象資料大全地震之部 }\end{array}$ & \\
\hline 328 & $\begin{array}{c}\text { Musha (1951) Japan Earthquake Historical Records.* } \\
\text { 武者金吉 }(1951) \text { 日本地震史料 } \\
\end{array}$ & Hsu and $\mathrm{Li}(1996)$ \\
\hline 329 & $\begin{array}{c}\text { Hsu (1955) The Earthquakes of Taiwan. (in Chinese) } \\
\text { 徐鐵良 (1955) 臺灣之地震 }\end{array}$ & \\
\hline 330 & $\begin{array}{l}\text { United Daily News/ May 25, 1960. (in Chinese) } \\
\text { 聯合報1960年5月25日/第三版 }\end{array}$ & \\
\hline 331 & $\begin{array}{l}\text { Hsu (1966) Seismicity of Taiwan. (in Chinese) } \\
\text { 徐明同 (1966) 臺灣地區地震活動研究報告 }\end{array}$ & \\
\hline 332 & Hsu (1971) Seismicity of Taiwan and Some Related Problems. & \\
\hline
\end{tabular}

Note: * refers to files which lack the original document. 
Table 2. (Continued)

\begin{tabular}{|c|c|c|}
\hline No. & Original document & Reference \\
\hline 333 & $\begin{array}{l}\text { Hsu (1983) Estimation of Earthquake Magnitudes and Seismic Intensities of Destructive Earthquakes in the Ming and Qing } \\
\text { Eras. (in Chinese) } \\
\qquad \text { 徐明同 (1983) 明清時代破壞性大地震規模及震度之評估 }\end{array}$ & \\
\hline 334 & Iida et al. (1967) Preliminary Catalog of Tsunamis Occurring in the Pacific Ocean. & \\
\hline 335 & Iida (1984) Catalog of Tsunamis in Japan and Its Neighboring Countries. & \\
\hline 336 & $\begin{array}{l}\text { Fang (1969) A Compilation of Historical Records of Taiwan Earthquake before the Twentieth Century. (in Chinese) } \\
\text { 方豪 (1969) 二十世紀以前臺灣地震記錄彙考 }\end{array}$ & \\
\hline 337 & $\begin{array}{c}\text { Tang (1971) Planning and Design of Coastal Engineering. (in Chinese) } \\
\text { 湯麟武 (1971) 海岸工程規劃設計 }\end{array}$ & \\
\hline 338 & $\begin{array}{c}\text { Sheng (1971) The Relief Business of Taiwan Disasters in Qing Era. (in Chinese) } \\
\text { 盛清沂 (1971) 清代本省之災荒救濟事業 }\end{array}$ & \\
\hline 339 & Soloviev and Go (1974) Katalog Tsunami na Zapadnom Poberezh'e Tikhogo Okeana. (in Russian) & \\
\hline 340 & Lee et al. (1976) A Catalog of Historical Earthquakes in China Compiled From Recent Chinese Publications. & \\
\hline 341 & $\begin{array}{c}\text { Institute of Geology, State Seismological Bureau, 1979. A summary Instruction on “The Seism Tectonic Map of the People’s } \\
\text { Republic of China” (with a brief catalogue of stronger earthquake in China). } \\
\text { 國家地震局地質研究所 (1979) 中華人民共和國地震構造圖簡要說明 (附中國強地震簡目) }\end{array}$ & \\
\hline 342 & $\begin{array}{c}\text { Hsu (1983) A Collection of Historical Materials of Taiwan Natural Disasters in Qing Era. (in Chinese) } \\
\text { 徐泓 (1983) 清代臺灣災害史料編彙 }\end{array}$ & \\
\hline 343 & $\begin{array}{c}\text { Yang et al. (1983) Mathematical Model for Calculation of Tsunami Propagation and Tsunami Run-up in the Northeastern Area } \\
\text { of Taiwan. (in Chinese) } \\
\qquad \text { 楊春生等 (1983) 台灣東北部海岸地震海嘯數值推算之研究 } \\
\end{array}$ & \\
\hline 344 & Tsai (1985) A Study of Disastrous Earthquakes in Taiwan, 1683-1895. & \\
\hline 347 & $\begin{array}{c}\text { Hsu and Li (1996) Tsunami in the Region near Taiwan. (in Chinese) } \\
\text { 許明光和李起肜 (1996) 台灣及其鄰近地區之海嘯 }\end{array}$ & \\
\hline
\end{tabular}

earthquake reports are deficient from this particular source.

\section{(2) Local version of the literature}

The literature in this category includes local chronicles, interview records, customs reports and the newspaper reports of the time which mainly documented local disaster situations. There are 20 local version files listed, among which, File No. 206, The North China Herald and Market Report of 8 January 1868, contains a detailed description of the disaster situation in the Tamsui and Keelung areas.

\section{(3) Personal records and articles}

There are 45 files comprising personal articles, travel stories, poems and letters, mostly personal observations (Table 2). Among them, two files contain complete depictions of the event. File No. 304, Journal of a Blockaded Resident in North Formosa During the Franco-Chinese War: 1884-5 (Dodd 1888) reveals that the author of this journal was present in Mankah when the earthquake hit. He rushed home to Keelung the next day and thoroughly described in his journal the damage in Keelung and Mankah and the flood caused by the tsunami. File No. 317, Terrain Changes Around Jinbaoli During the Tongzhi Years (Okamoto 1913), gives a detailed account of the amount of damage and loss from the earthquake and the tsunami in the Jinbaoli area.

\section{(4) Temple establishment histories and epigraphs}

In this category documents are collected from temple chronicles and establishment histories, epigraphs on the steel and interviews held on the spot. The content focuses on describing the condition of collapsed buildings and the reconstruction work on the temples and nearby areas. There are eleven files obtained from four temples (Cihu Temple, Guangan Temple, Ching-shui Patriach Temple, and Qingan Temple), two old houses (Huang's Old House and Chi-feng Old House), three tourist attractions (Jinbaoli old street, Huang-zui Roar Smoke, and Keelung Mountain), and field interviews in two places (Four Rivers in Keelung, Bachimen, and Uhr Sha Wan).

\subsection{Data Reliability Analysis}

As stated above, there are 76 historical documents related to the 1867 Keelung earthquake and tsunami. Some of them only briefly describe the event, some are derivative and some contain contradictory statements about the same event. It is therefore necessary to carry out a data reliability analysis to examine and verify the original source, the integrity of the documents and the authenticity of the contents and the authors.

\subsection{Verification of Place Names in the Literature}

Northern Taiwan has been under the rule of the Spanish, the Dutch, the Ming Dynasty, and the Qing Dynasty, the Japanese and briefly the French in terms of its history. Thus, place names in different documents may vary with the 
languages used and translation deviations by which different names of places could possibly mean the same location. Furthermore, as time went by, place names and administrative regions changed a lot. It is significant to identify the places named in the documents and correlate them with old maps. For instance, File No. 206, The North China Herald and Market Report, stated that "in Pa tsien na, 150 persons were killed". In File No. 208, Tamsui Trade Report for the year 1881, stated that "Pachena was partially laid in ruins". In File No. 311, Dainippon Dictionary of Place Name Sequel (in Japanese), stated that in Shilin Old Street more than half of the town was destroyed. Comparing the locations of Pa tsien na, Pachena, and Shilin Old Street in the old maps, they all indicate the same place which is Shilin today and was known as Pattsiran in the past, which has the meaning 'hot spring' for the indigenous Pingpu Tribe. Palm Island and Bush Island, which are named in many documents, are correlated with the current Heping Island and the nearby Tongpan Islet when compared with the French maps illustrated by Garnot (1884) and the map of North Formosa (No. 208) from Hancock (1882). The inundated area of Badouzi mentioned in File No. 317, Terrain Changes Around Jinbaoli During the Tongzhi Years, was once mistaken to refer to Badouzi Fishing Port in east Keelung. From the de- scription given in the document, it should be located near Jimbaoli (Jinshan). After accessing a Taiwan Fort Map $(1 / 20000)$ published in 1904, it is clear that Badouzi is located on the site of the present Second Nuclear Power Plant in Wanli. It did not show up on the map because the village Badouzi had been relocated since the power plant was established. The English and Chinese names for each locality are listed in Table 3.

\subsection{Evaluation of the Corresponding Tsunami Height and Intensity}

Based on the foregoing disaster information compiled from various places we can now apply the Central Weather Bureau Intensity Scale (Table 4) to assess the quake intensity of the regions involved. The related accounts of tsunami run-up height and inundation areas will be taken into consideration to estimate the tsunami wave height and run-up height along the topography. For example, File No. 304, Dodd (1888), described the sight of the tsunami in the bay of Keelung Harbor when he returned to his home in Keelung on the day after the earthquake: "The tide in Keelung only rises three feet for most at any time, and during the earthquake referred to the extra rise above high water

Table 3. The English and Chinese names for the relevant localities.

\begin{tabular}{ll}
\hline \multicolumn{1}{c}{ English name } & \multicolumn{1}{c}{ Chinese name } \\
\hline Kim-pau-li, Jinbaoli (Jinshan) & 金包里(新北市金山) \\
\hline Jinbaoli Old Street & 金包里老街 \\
\hline Cihu Temple (Jinshan Mazu Temple) & 金包里慈護官(金山媽祖廟) \\
\hline Huang's Old House & 金山黄氏古厝 \\
\hline Chi-feng Old House & 金山芦豐居老厝 \\
\hline Guangan Temple & 金山廣安宮 \\
\hline Huanggang & 新北市金山區磺港 \\
\hline Suiwei & 新北市金山區水尾 \\
\hline Shanjetain & 新北市金山區三界壇 \\
\hline Huang-shi-tou & 新北市金山區磺溪頭 \\
\hline San-zhon-Qiao & 新北市金山區三重橋 \\
\hline Twin Candlestick Rock & 燭台雙嶼 \\
\hline Wanli & 新北市萬里 \\
\hline Huang-ku & 磺堀(新北市萬里區) \\
\hline Badouzi (the Second Nuclear Power Plant site now) & 八斗仔(現今核二廠廠址) \\
\hline Daping & 新北市萬里區大坪 \\
\hline Geng-zi-ping & 新北市萬里區焿子坪 \\
\hline Huang River & 磺溪 \\
\hline Jinbaoli River & 金包里溪 \\
\hline Huangzuishan & 磺嘴山 \\
\hline Huang-zui Roar Smoke & 磺嘴吼煙 \\
\hline Keelung-tou, Kelung (Keelung) & 雞笠頭(基隆) \\
\hline Keelung Harbor & 基隆港 \\
\hline Ta-sha-wan & 大沙灣(基隆市中正區) \\
\hline Uhr Sha Wan & 二沙灣(基隆市中正區) \\
\hline
\end{tabular}


Table 3. (Continued)

\begin{tabular}{ll}
\hline \multicolumn{1}{c}{ English name } & \multicolumn{1}{c}{ Chinese name } \\
\hline Image Point (Lohan) & 萬人鼻堆(基隆市中山區) \\
\hline Qingan Temple & 基隆市慶安宮 \\
\hline Bachimen & 基隆港八尺門 \\
\hline Palm Island (Heping Island) & 棕梠島(基隆市和平島) \\
\hline Bush Island (Tongpan Islet) & 灌木島(基隆市桶盤嶼) \\
\hline Keelung Mountain & 基隆山(新北市瑞芳區) \\
\hline Badouzi Fishing Port & 八斗子漁港(基隆市中正區) \\
\hline Tamsui River & 淡水河 \\
\hline Tamsui, Hobe & 淡水, 滬尾 \\
\hline Piatow & 鼻仔頭(新北市淡水區) \\
\hline Ching-shui Patriach Temple & 淡水清水祖師廟 \\
\hline Shimen & 新北市石門 \\
\hline Alipound & 阿里磅(新北市石門區) \\
\hline Sanzhi & 新北市三芝 \\
\hline Pa tsien na, Pachena, Pattsiran (Shilin) & 八芝蘭(士林) \\
\hline Tataocheng & 大稻埕(台北市大同區) \\
\hline Mankah & 艋舺(台北市萬華區) \\
\hline Miaoli & 苗栗 \\
\hline Taichung & 台中 \\
\hline Fengyuan & 豐原 \\
\hline Shanghai & 上海 \\
\hline Zhejiang Xiangshan & 浙江象山 \\
\hline Zhejiang Ningbo & 浙江寧波 \\
\hline Jiangxi Jiujiang & 江西九江 \\
\hline Hangchow & 杭州 \\
\hline Hankow (French) & 漢口 \\
\hline Yangtze River & 揚子江 \\
\hline iantang River & 錢塘江 \\
\hline rovince de Chanse (French) & 江西省 \\
\hline
\end{tabular}

Table 4. Central Weather Bureau Intensity Scale.

\begin{tabular}{ccl}
\hline Intensity & PGA (gal) & \\
\hline 0 Micro & $<0.8$ & Not felt. \\
\hline 1 Very minor & $0.8-2.5$ & Felt only by a few people at rest, vibrates slightly. \\
\hline 2 Minor & $2.5-8.0$ & $\begin{array}{l}\text { Felt by the majority of people. Some awakened from sleeping. } \\
\text { Hanging lamps and objects vibrate slightly. } \\
\text { Standing vehicles vibrate slightly, similar to being passed by a truck, but only lasts for a short time. }\end{array}$ \\
\hline 3 Light & $8.0-25$ & $\begin{array}{l}\text { Felt by nearly everyone, a few frightened. } \\
\text { Buildings shake; dishes, windows, and doors shake making sounds; hanging objects shake visibly. } \\
\text { Standing vehicles vibrate obviously; electric wires sway gently. }\end{array}$ \\
\hline Moderate & $25-80$ & $\begin{array}{l}\text { Many people are quite frightened, looking for safe shelter. Most people are awakened from sleep. } \\
\text { Buildings rock noticeably; unstable objects topple over; heavy furniture moves; may cause slight damage. } \\
\text { Felt by drivers; electric wires sway obviously, felt by people walking. }\end{array}$ \\
\hline 5 Strong & $80-250$ & $\begin{array}{l}\text { Most people are considerably frightened. } \\
\text { Walls crack; heavy furniture may overturn. } \\
\text { Noticeably felt by drivers; some chimneys and large archways topple over. }\end{array}$ \\
\hline 6 Very Strong & $250-400$ & $\begin{array}{l}\text { People have trouble walking due to violent rocking. } \\
\text { Damage to some buildings; heavy furniture overturns; doors and windows bend. } \\
\text { Drivers have trouble steering; sand and clay blasts occur. }\end{array}$ \\
\hline 7 Great & $>400$ & $\begin{array}{l}\text { People move with difficulty due to severe rocking. } \\
\text { Severe damage to or collapse of some buildings; almost all furniture moves or falls down. } \\
\text { Landslides and faults rupture occur; railway bend; underground lines break. }\end{array}$ \\
\hline
\end{tabular}


mark was not more than five feet." and "On visiting Keelung just after the earthquake, the damage to our Chinese house, which was only about four to five feet above the level of the high water mark, was simply nil, the water having risen above the flooring only." From this description, it would appear that the wave rose around five feet in height $(152.4 \mathrm{~cm})$ above the high water mark in the bay. If the arrival time of the tsunami can be determined, the rough height of the tsunami in Keelung Harbor could be calculated from the tide height of the time. Dodd's home was a traditional Chinesestyle house near the harbor and was five feet higher than the high water mark. The house flooded only at the floor level, which could also be an indicator of the run-up height of the tsunami in Keelung Harbor. In Jinshan, as recorded in File No. 317, Okamoto (1913) interviewed two elders and was told that, "The earthquake hit at the start, the sea was choppy five minutes later. After half an hour, the ocean floor was exposed for about four or five hundred meters away from the shore (it looked not far because of the depth of the sea). One hour later, sea water gushed over and the tsunami occurred. Sea water flowed out and flooded Huanggang and Suiwei and the wave height was up to two zhangs (a unit of length). Jinbaoli streets and the Badouzi region were inundated in the seawater." Although the interview took place about 46 years after the tsunami and there might be some deviation between the actual event and what the elders could recall, this is the only account that includes precise numerical information about the tsunami in the Jinshan region. At that time, the unit of length used in Taiwan was the zhang, which is about $3.03 \mathrm{~m}$. Hence, the wave height observed in Huanggang and Suiwei can be calculated to have been around $6 \mathrm{~m}$. With this information indicating that Jinbaoli and Badouzi were inundated by the seawater, the topography can be used to obtain the elevations of the two places and then to assess the tsunami run-up height.

\subsection{Building a Spatial Distribution}

Applying the foregoing damage distribution and tsunami information to the maps of the time, which include the attached map of North Formosa (No. 208) by Hancock (1882), the Taiwan Fort Map (1/20000) published in 1904, and the French map illustrated by Garnot (1884), GIS (Geographic Information Systems) tools were used to show the damage spatial distribution on the present-day map and display the likely isoseismic map.

\subsection{Assessing the Source Parameters}

According to the earthquake intensity distribution map thus designed, the relevant geological and geophysical data for active faults and seabed terrain can be consulted to assess the possible source parameters and faults. The empirical rupture length vs. magnitude formula (Wells and Cop- persmith 1994) were applied to estimate the corresponding earthquake magnitude:

Normal fault

$$
\begin{aligned}
& \mathrm{M}_{\mathrm{w}}=4.86+1.32 \log (\mathrm{SRL}) \pm 0.34\left(5.2<\mathrm{M}_{\mathrm{w}}<7.3\right) \\
& \mathrm{M}_{\mathrm{w}}=4.34+1.54 \log (\mathrm{RLD}) \pm 0.31\left(5.2<\mathrm{M}_{\mathrm{w}}<7.3\right) \\
& \log (\mathrm{RW})=-1.140+0.350 \mathrm{M}_{\mathrm{w}} \pm 0.12\left(5.2<\mathrm{M}_{\mathrm{w}}<7.3\right)
\end{aligned}
$$

In the above formulas, SRL refers to surface rupture fault, RLD refers to subsurface rupture fault, and RW refers to rupture width. In Wells and Coppersmith's (1994) study, moment magnitude $\left(\mathrm{M}_{\mathrm{w}}\right)$ was used for measurement. Even so, according to Cheng et al.'s (2011) experience, this study will adopt local magnitude $\left(\mathrm{M}_{\mathrm{L}}\right)$ as the most commonly used measure of magnitude in Taiwan:

$\mathrm{M}_{\mathrm{L}}=5.115 \ln \left(\mathrm{M}_{\mathrm{w}}\right)-3.131 \pm 0.379\left(\mathrm{M}_{\mathrm{L}}>5.5\right)$

Using fault length variables of 30,40 , and $50 \mathrm{~km}$ and surface and subsurface rupture types, six models are produced for testing (Table 5). It is assumed that the hypocenter is located in the center of the fault plane, thus six groups of source parameters can be obtained.

\subsection{Simulating an Isoseismic Map to Evaluate Source Parameters}

Finally, the attenuation law was used to simulate the isoseismic map in the Taiwan area. By correlating the isoseismic map to the disaster distribution, the validity of the source parameters can be probed. Empirical attenuation laws of Shin (1998) and Jean et al. (2006) were both used to carry out the simulation. Comparing the differences between the isoseismic map generated from PGA and the isoseismic map produced from the observed disaster distribution, the resulting source parameters are expected to be reliable.

The relationships were:

$\mathrm{Y}(\mathrm{g})=$
$0.00284 \mathrm{e}^{1.73306 \mathrm{M}}[\mathrm{R}+0.09994 \exp (0.77185 \mathrm{M})]^{-2.06392}$

where $\mathrm{g}$ is acceleration, $\mathrm{M}$ is local magnitude and $\mathrm{R}$ is

Table 5. Six types of fault length vs. magnitude.

\begin{tabular}{c|ccc|ccc}
\hline \multirow{2}{*}{$\begin{array}{c}\text { Fault } \\
\text { Length }\end{array}$} & \multicolumn{2}{|c|}{ Surface rupture (SRL) } & \multicolumn{3}{c}{ Subsurface rupture (RLD) } \\
\cline { 2 - 7 } & $\mathbf{R W}$ & $\mathbf{M}_{\mathrm{w}}$ & $\mathbf{M}_{\mathbf{L}}$ & $\mathbf{R W}$ & $\mathbf{M}_{\mathbf{w}}$ & $\mathbf{M}_{\mathbf{L}}$ \\
\hline $30 \mathrm{~km}$ & 17.4 & 6.8 & 6.7 & 14.8 & 6.6 & 6.5 \\
$40 \mathrm{~km}$ & 20.4 & 7.0 & 6.8 & 17.4 & 6.8 & 6.7 \\
$50 \mathrm{~km}$ & 22.1 & 7.1 & 6.9 & 20.4 & 7.0 & 6.8 \\
\hline
\end{tabular}


hypocenter distance (Jean et al. 2006) and

$$
\mathrm{PGA}=12.44 \times \exp (1.31 \times \mathrm{M}) \times \mathrm{R}^{-1.837}
$$

where $\mathrm{M}$ is local magnitude, $\mathrm{R}$ is hypocenter distance (Shih 1998):

\section{RESULTS AND DISCUSSION}

\subsection{Summary of Literature Documents}

Currently, 76 historical documents related to the 1867 Keelung earthquake and tsunami are known and accessible, comprising 20 local versions from the literature (Table 1), 45 personal records and articles (Table 2) and 11 temple establishment histories and epigraphs. However, documents from official records are still missing and we propose to make every effort to find them in the future. These original data and files will be input to the website: The Data-Base of Historical Earthquake Documents in Taiwan (http://tc .earth. sinica.edu.tw/TEM/hisevent/hisdoc.php) to enrich the integrity of the database.

\subsection{Implications for the Tsunami Height}

According to File No. 339, Soloviev and Go (1974), "Another Survey (Perrey, 1872) mentions that in 1867 (date and month not indicated), an unusual flood tide was observed at Hangchow (China). The level of the Yantzekiang River suddenly dropped $135 \mathrm{~cm}$ (4 feet 6 inches) and then rose $150 \mathrm{~cm}$ ( 5 feet 6 inches) in 48 hours. It is possible that this was an effect of the Taiwan tsunami." It is doubtful that the river winding through Hangchow is referred to as the Qiantang River instead of the Yangtze River. In addition, the duration of the fall and rise of the river persisted for $48 \mathrm{~h}$ without a clear date being mentioned. This behavior is distinct from the physical characteristics of tsunamis. The description quoted Perrey's (1872) report in French (No. 302), and referred to a report in the New Orleans Times of 24 December 1867; "The river in Hankow dropped 4 feet 6 inches suddenly and then rose 5.5 feet in 48 hours. The Chinese said, in the province of Chanse, that water erupted from the ground and submerged the city." There is no date mentioned in this quotation. While Hankow is in the middle reach of the Yangtze River, the river water displacement should be unconnected with the Keelung tsunami.

File No. 206 (The North China Herald and Market Report of 8 January 1868) is a record of Keelung Harbor bay: "... the water of the harbor rushing out seawards, leaving it dry as far as Ruin Rock for some seconds". The location of Ruin Rock can be confirmed by Dodd's (1888) statement that Ruin Rock was located near Image Point and on the west side of the harbor entrance. Image Point could possibly be the spot where the Keelung Lighthouse (Lohan) is now.
The record showed that the water retreated to the harbor entrance and drained the bay.

Twelve documents contain detailed descriptions about the time when the earthquake and tsunami occurred, such as File No. 206 (The North China Herald and Market Report of 8 January 1868) which recorded that "The earthquake struck Tamshui at 10:20 am and hit Keelung at 09:45 am. There was a 45-minute time difference between the two places about the time the earthquake happened." The author of that document thought that it was normal to have a time variation within half an hour between watches. According to this report after the earthquake, water in the harbor bay rushed away from the shore as far as Ruin Rock and the bay was drained for several seconds. Everything was swept away by the retreating water. The water then returned in two big waves. Hancock (1882) (No. 208) gave a similar description. Holt (1868) (No. 301) noted the interval for the tsunami's return as "a few moments" and remarked that the tsunami came in one big wave rather than two. Perrey (1872) (No. 303) and Soloviev and Go (1974) (No. 339) gave the same account. Dodd (1888) (No. 304), however, pointed out that there was a mistake in Hancock's (1882) description of the time interval: "In the 1867 earthquake, when the water left the harbor of Keelung, leaving it dry and returning again in a few minutes - not seconds as stated by Mr. Hancock in his Customs Report. People went down into the harbor to pick up fish and the disaster happened when water rushed back." Mackay (1896) (No. 305) also made the same statement. According to Davidson (1903) (No. 307) description: "The force of the earthquake may be judged when it is noted that the water of Keelung harbor ran out, leaving the bottom of the bay exposed. Fortunately there were no foreign vessels present, but the Chinese junks which were there, large and small, were in one second left dry on the bottom and in another caught by the huge returning wave to be either swamped or dashed into the town with fearful speed, to work havoc among the few remaining houses left near the shore." Alvarez (1915) (No. 319), Fang (1969) (No. 336), and Hsu (1983a) (No. 342) gave similar descriptions. The Taihoku Meteorological Observatory (1914) (No. 318) noted that "At 10:00 am a violent earthquake hit, after that the water in the Keelung Harbor withdrew and the seabed was exposed. The returning giant wave formed a tsunami." Okamoto (1913) (No. 317) stated that "In Jinshan, a strong earthquake struck at 10:00 am; 30 minutes later, the ocean floor was exposed about for four or five hundred meters away from the shore. An hour later, sea water gushed over and a tsunami occurred; 70 or 80 people were swallowed up by tsunami while picking up fish at the time of water receding." Among these documents, Files No. 206, 317, and 318 stated that the earthquake occurred at around 10:00 am. Twelve of the documents indicated there was no obvious foreshock and that the first hit caused immediate damage. In Jinshan and Keelung Harbor, 
according to the records, people were swept away by the tsunami while picking up fish during the period when the water had withdrawn. Hence, it can be inferred that the duration of the water's withdrawal lasted for a while rather than a few seconds, as Files No. 206 and 208 stated. The tsunami hit Jinshan about one hour after the earthquake and brought havoc. Although damage was caused in Keelung Harbor, there was no accurate time description. The earthquake happened on 23 November in the lunar calendar during the Last Quarter. During that period, tidal ranges are not influenced by the alignment of the sun and the moon or by the shape of the coastline and nearshore bathymetry. Using the Tide Tables from the Marine Meteorology Center (2013) and Su and Lee (2014) as references, there were two lunar dates marked 23 November 2013 which were 4 January and 25 December. The Tide Tables of Keelung Harbor recorded a high tide at 01:42, a low tide at 07:25, a high tide at 14:54, and a low tide at 21:13, and an average height difference of $58.2 \mathrm{~cm}$ on 4 January 2013. On 25 December, the Tide Tables noted a high tide at 02:29, a low tide at 08:13, a high tide at 15:38, and a low tide at 22:07, and an average height difference of $51.3 \mathrm{~cm}$. The 1867 tsunami is estimated to have hit Keelung at 11:00 am, which was the time of the ebb, and the tide was due to rise to a height of $22.6 \mathrm{~cm}$ above the low water mark.
There are only detailed reports in the sorted files about the tsunami attack effects in Jinshan and Keelung Harbor. Okamoto (1913) (No. 317) noted that "The height of the wave in Huanggang and Suiwei was about $6 \mathrm{~m}$. After the tsunami, Jinbaoli streets and the Badouzi region were inundated by the seawater." With the assumption that there had been little change in the topography between 1867 and 1904, a run-up height of the tsunami in the Jinshan region can be calculated by consulting the Taiwan Fort Map published in 1904 (Temporary Taiwan Land Investigation Bureau 1904). Figure 2, picture A displays the Jinshan topography at a contour interval of 50 feet $(15.2 \mathrm{~m})$. In Jinshan the Huang River runs through the northwest of Jinbaoli Old Street and Jinbaoli River lies to the southeast. The yellow block in the middle represents buildings in the area. The region altitude is $15 \mathrm{~m}$ above sea level, which indicates that the tsunami run-up was $15 \mathrm{~m}$. It is speculated that the seawater moved along the river and caused the Jinbaoli Old Street inundation. Figure 2, picture B shows the Badouzi topography. The yellow block represents the building concentration at $15 \mathrm{~m}$ above sea level. A hill over 150 feet high $(45 \mathrm{~m})$ with two streams winding past lies between the coastline and the built-up zone. It can be surmised that the tsunami did not hit Badouzi directly. The water came along the streams and inundated Badouzi village. Hence, the run-up height of

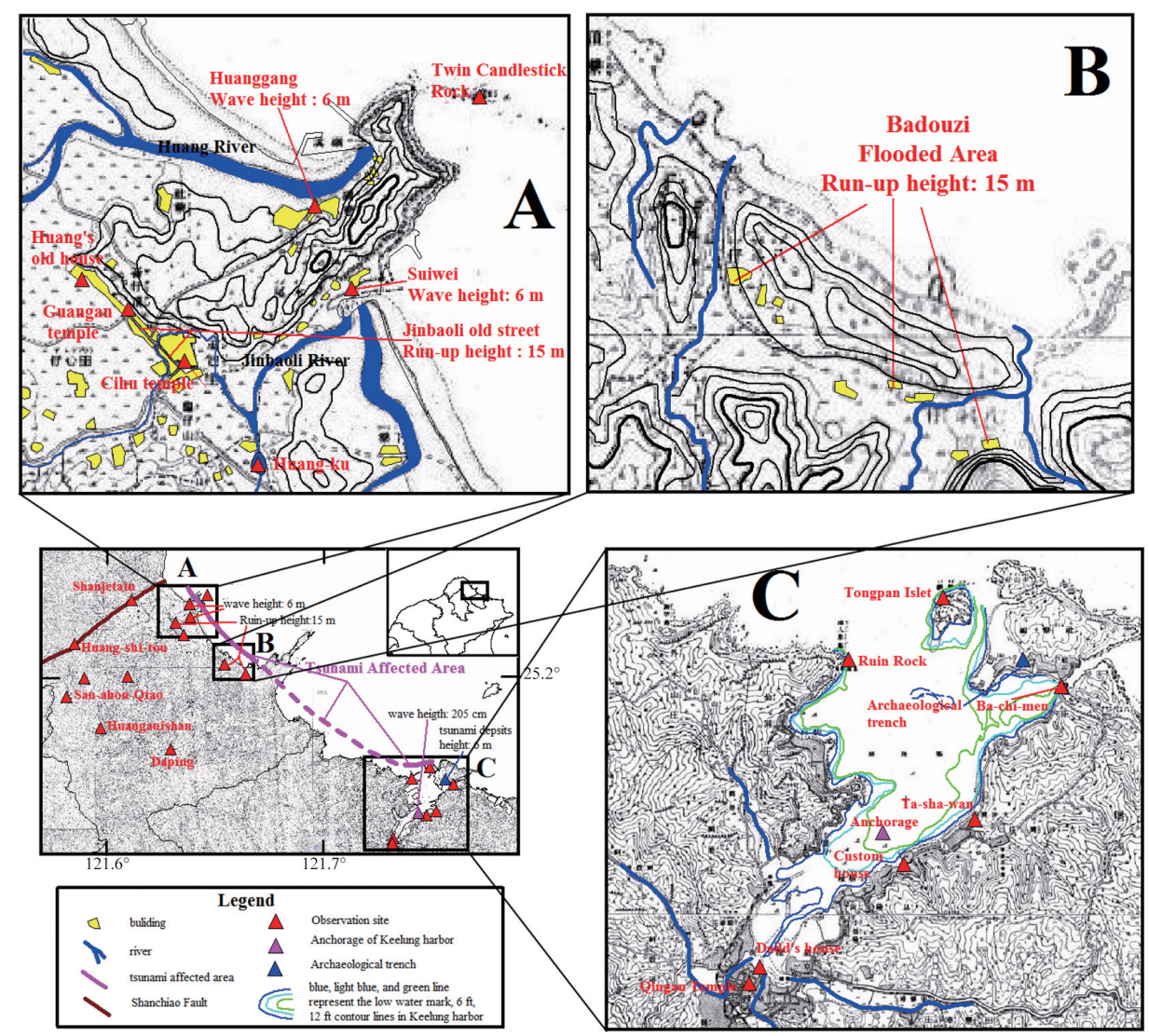

Fig. 2. The affected area distribution of the Keelung Tsunami. A. Jinshan area; B. Badouzi area; C. Keelung Harbor bay area. (Color online only) 
the tsunami in the Badouzi area is estimated to have been higher than $15 \mathrm{~m}$. A tsunami's run-up height is affected by the local geography, slope and nature of the soil and rocks. Since the Second Nuclear Power Plant has changed the local landform, it is worth noting that the location has a tsunami run-up of over $15 \mathrm{~m}$ height on the record.

Descriptions of the Keelung Harbor tsunami attack are many, and among them, Files No. 206, 304, and 307 are well documented. The available data were integrated to reconstruct the time of the tsunami. Here is the possible scenario for the event. A violent earthquake hit between 09:45 and 10:00 am. The shock lasted for $15-30 \mathrm{~s}$. The ground cracked in front of the Keelung Customs House. Most of the houses collapsed in Keelung, Ta-sha-wan and Uhr Sha Wan. Observed from Heping Island, Keelung Islet, and Tongpan Islet, massive vapor and water columns rose from the sea surface. The water in the harbor rushed out and left it dry as far as Ruin Rock. The bay was drained and the four major rivers nearby Keelung Harbor dried up, which beached the ships on the exposed seabed. After a while, the water returned in a giant tide. The seawater came back with a lot of pumice and rushed onto the Tongpan Islet beach. The wooden boats that were grounded in the bay were swallowed up by the tsunami and many coastal colliers were overturned or drowned. The bottom plates of an old sailing boat grounded on the shallow water area at Uhr Sha Wan was carried all the way to the opposite village and pieces of its timbers were scattered south of the gulf. People were drowned by the rushing water when disembarking from the grounded sailing boat. Village residents in Ta-sha-wan and Bachimen were swept away by the returning water while they were picking up fish during the water's withdrawal period. Water swept over the dikes and smashed the low-lying coastal houses. Hundreds of fish were washed up the shore and quickly picked up by the residents. Keelung has an average rise in sea level of three feet at high water. The tsunami run-up was around $150 \mathrm{~cm}$ above the high water mark. With the available information and the knowledge that the tide was on the ebb, the water was below sea level with a height of $22.6 \mathrm{~cm}$ higher than the low water mark and the difference between the high and low water marks was $54.8 \mathrm{~cm}$. Thus, an estimate can be made that the sea level before the tsunami was $46 \mathrm{~cm}$ below the high water mark and that the tsunami run-up height in the Keelung Harbor bay was less than $205 \mathrm{~cm}$. Dodd's Chinese-style house near the harbor was five feet higher than the high water mark. The house was flooded only on the floor with no great damage; even the wood pile by the door near the water was not swept away. The damage situation in Keelung City was slight. Qingan Temple in Keelung was unharmed and not flooded. The foregoing materials show that the inundation height in Keelung City was between 175 and $205 \mathrm{~cm}$, whereas the wave height observed in the bay was not much different from that. A possible reason for this is that the tide was on the ebb when the earthquake hit and the water reced- ed, forming shallows for a distance (Dodd 1888). In Fig. 2, picture $\mathrm{C}$, the segments delineated by blue, light blue, and green lines represent the low water mark, the $6 \mathrm{ft}$. contour line and $12 \mathrm{ft}$. contour line, respectively. The waterline on the ebb is calculated as being $1.5 \mathrm{~km}$ away from Keelung City. Therefore, after running through the shallows, which reduced its energy, the tsunami with a run-up height of $205 \mathrm{~cm}$ in the bay swept into Keelung City and affected only the houses along the coast. After the tsunami the depth of the water was a few meters deeper at the rest of the berth for vessels in Uhr Sha Wan, which could have been caused by the tsunami washout instead of a subsidence phenomenon. According to the Central Geological Survey results, a $5-15 \mathrm{~cm}$ thick layer of tsunami deposits was found near the Heping island trench with the upper layer at approximately $6 \mathrm{~m}$ above sea level. This deposit is inferred to have been from the 1867 tsunami (Jhuang et al. 2012). This result offers some support for the description of the sweeping away of people while picking up fish during the ebb in Bachimen and the tsunami attack on Heping Island. There is clear and convincing evidence that Jinshan, Badouzi and Keelung Harbor were devastated by the tsunami and it can be inferred that the tsunami hit along the coast from Jinshan to Keelung and caused severe damage.

\subsection{Implications for Locating the Earthquake Source}

Soloviev and Go (1974) (No. 339) included a piece of information related to the Keelung earthquake: "Perrey (1873) cites reports from London and New York published in The Times of 11 and 12 February 1868 that an earthquake which frightened the inhabitants occurred at Shanghai. The date of the earthquake is not mentioned." This press report implied that the Keelung earthquake had an impact on Shanghai. According to news reports in the North China Daily News of 19, 20, and 27 December 1867 (No. 101, 102, 104), between 09:30 and 10:00 on 17 December 1867, the impact of an earthquake was felt in Jiangsu Shanghai, Zhejiang Ningbo, and Jiangxi Jiujiang. Zhejiang Ningbo felt the quake intensely: "The bells rang and the clocks stopped. Candle holders toppled down. The water in the water tanks swayed and ripples radiated outwards." This description matches level 4 on the intensity scale. However, this reported earthquake is considered to have been a different one occurring somewhere in China and has no relevance to the Keelung earthquake on 18 December 1867. Only Zhejiang Xiangshan felt the earthquake on 18 December 1867 according to File No. 113, Cheng and Chen's (1927) Annals of Xiangshan County.

From the sorted 76 documents, the earthquake intensity and the damage caused in various regions were categorized and applied to the Central Weather Bureau Intensity Scale (Table 4). The results are shown in Table 6 and generate an intensity distribution and isoseismic map as shown in Fig. 3. 
The regions that radiated from Badouzi, Jinshan, and Shanjetain were the most severely damaged (the shadowed area in Fig. 3). More than half of the houses were destroyed, which represents a level 6 or 7 on the Intensity Scale. In Huang$\mathrm{ku}$, a hot spring erupted from the paddy field to a height of up to $12 \mathrm{~m}$. Many people were burned and one person was killed. The land on the spot where the hot spring erupted had fallen and formed a pond of 10 - 13 square meters after the earthquake which measured 6 or 7 in intensity. In 1912 an investigation found that the pond had become enlarged to the size of 1322 square meters (No. 315) which presently still exists. Almost half of the houses collapsed in Huanggang. A hot spring burst from the sand on the beach to a height of $9 \mathrm{~m}$ and erupted continuously for three days. This event rates as 6 or 7 in intensity. In Suiwei most of the houses toppled over, a hot spring spewed out on waste ground for three days to a height of $9 \mathrm{~m}$, and the intensity is estimated to have been 6 or 7 . The losses caused by the disaster were milder in Daping and Alipound, at the scale of 6. It is worth noting that Twin Candlestick Rock subsided by $3 \mathrm{~m}$. Along the onshore Shanchiao Fault ground subsidence and cracking were found in Shanjietain and Huang-shi-tou. A

Table 6 . The corresponding intensity to disaster situation of each place affected by the 1867 Keelung Earthquake.

\begin{tabular}{|c|c|c|}
\hline Place name & Disaster Situations & Intensity \\
\hline Jinshan & $\begin{array}{l}\text { More than half of the houses were completely destroyed. Cihu Temple (Jinshan Mazu Temple), Guangan Temple, the } \\
\text { Huang's old house, and Jinbaoli old street were collapsed. Among the area, Badouzi, Jinbaoli, and Shanjetain were the } \\
\text { most severely damaged. }\end{array}$ & $6-7$ \\
\hline Huanggang & $\begin{array}{l}\text { Almost half of the houses collapsed completely. On the beach, a hot spring burst from the sand to a height of } 9 \mathrm{~m} \text { and } \\
\text { erupted continuously for three days. }\end{array}$ & $6-7$ \\
\hline Suiwei & Most of the houses toppled over, a hot spring spewed out on waste ground for three days to a height of $9 \mathrm{~m}$. & $6-7$ \\
\hline Badouzi & The regions which radiated from Badouzi, Jinbaoli and Shanjetain were the most severely damaged. & $6-7$ \\
\hline Shanjetain & $\begin{array}{l}\text { Ground subsidence and cracking occurred. Chi-feng old house (the Liqifeng House) collapsed. Badoui-zu, Jinbaoli, and } \\
\text { Shanjetain were the worst disaster center. }\end{array}$ & $6-7$ \\
\hline Huang-shi-tou & Ground subsidence and cracking occurred in many places. & 6 \\
\hline San-zhon-Qiao & Severe landslides occurred in Huangzuishan. & 6 \\
\hline Huang-ku & $\begin{array}{l}\text { A hot spring erupted from the paddy field to a height of up to } 12 \mathrm{~m} \text {. Many people were burnt and one person was killed. } \\
\text { The land on the spot where the hot spring erupted had fallen and formed a pond of } 10 \text { to } 13 \text { square meters. In 1912, an } \\
\text { investigation found the pond had become enlarged to the size of } 1322 \text { square meters which presently still exists. }\end{array}$ & 6 \\
\hline Daping & Damage was milder in Badouzi, Jinbaoli, and Shanjetain. & 6 \\
\hline Alipound & Damage was milder in Badouzi, Jinbaoli, and Shanjetain. & 6 \\
\hline Geng-zi-ping & $\begin{array}{l}\text { The quake caused a landslide of } 600 \text { - } 700 \mathrm{~m} \text { in length in Huangzuishan and formed a gorge through which flowed a hot } \\
\text { spring stream containing sulfur. }\end{array}$ & 6 \\
\hline $\begin{array}{l}\text { Twin Candlestick } \\
\text { Rock }\end{array}$ & Twin Candlestick Rock subsided by $3 \mathrm{~m}$. & $6-7$ \\
\hline Keelung & The city and nearby towns were smashed badly. & 6 \\
\hline $\begin{array}{l}\text { Uhr Sha Wan } \\
\text { Ta-sha-wan }\end{array}$ & $\begin{array}{l}\text { Most houses toppled and many people were buried in the debris. The ground cracked in front of Keelung Customs } \\
\text { House in Uhr Sha Wan. }\end{array}$ & 6 \\
\hline Keelung Mountain & Mountain crumbled. & 5 \\
\hline Shimen & $\begin{array}{l}\text { The village Shimen was considerably damaged, however no one was hurt because the villagers all rushed out to see } \\
\text { what had happened. }\end{array}$ & 6 \\
\hline Tamsui & $\begin{array}{l}\text { The major damages occurred on the hill behind the Hobe market. Houses tumbled and many were killed, } 30 \text { deaths were } \\
\text { estimated. }\end{array}$ & 5 \\
\hline Piatow & The walls of former British Merchant Warehouse cracked, the roof tiles fell and broke and the mud walls shattered. & 5 \\
\hline Shilin (Pa tsien na) & Half of Shilin old street (Pa tsien na) was struck seriously and 150 people were killed. & 6 \\
\hline Sanzhi & Damages recorded. & 5 \\
\hline Mankah & $\begin{array}{l}\text { Slight damage was recorded. Mud houses crashed in the suburbs. A big crack appeared on the Mankah Plain. The } \\
\text { surface of Tamsui River was bubbling like boiling water, the mud and trash on the river bed had been brought up to the } \\
\text { surface. }\end{array}$ & 5 \\
\hline Tataocheng & $\begin{array}{l}\text { The quake didn't cause widespread damage, a two-story building built about } 15 \text { or } 16 \text { years previously stood firmly } \\
\text { after the shock. }\end{array}$ & 5 \\
\hline Miaoli & Felt large earthquake. & 3 \\
\hline Taichung & Felt large earthquake. & 3 \\
\hline Fengyuan & Felt large earthquake. & 3 \\
\hline Xiangshan & Felt the earthquake slightly. & 1 \\
\hline
\end{tabular}




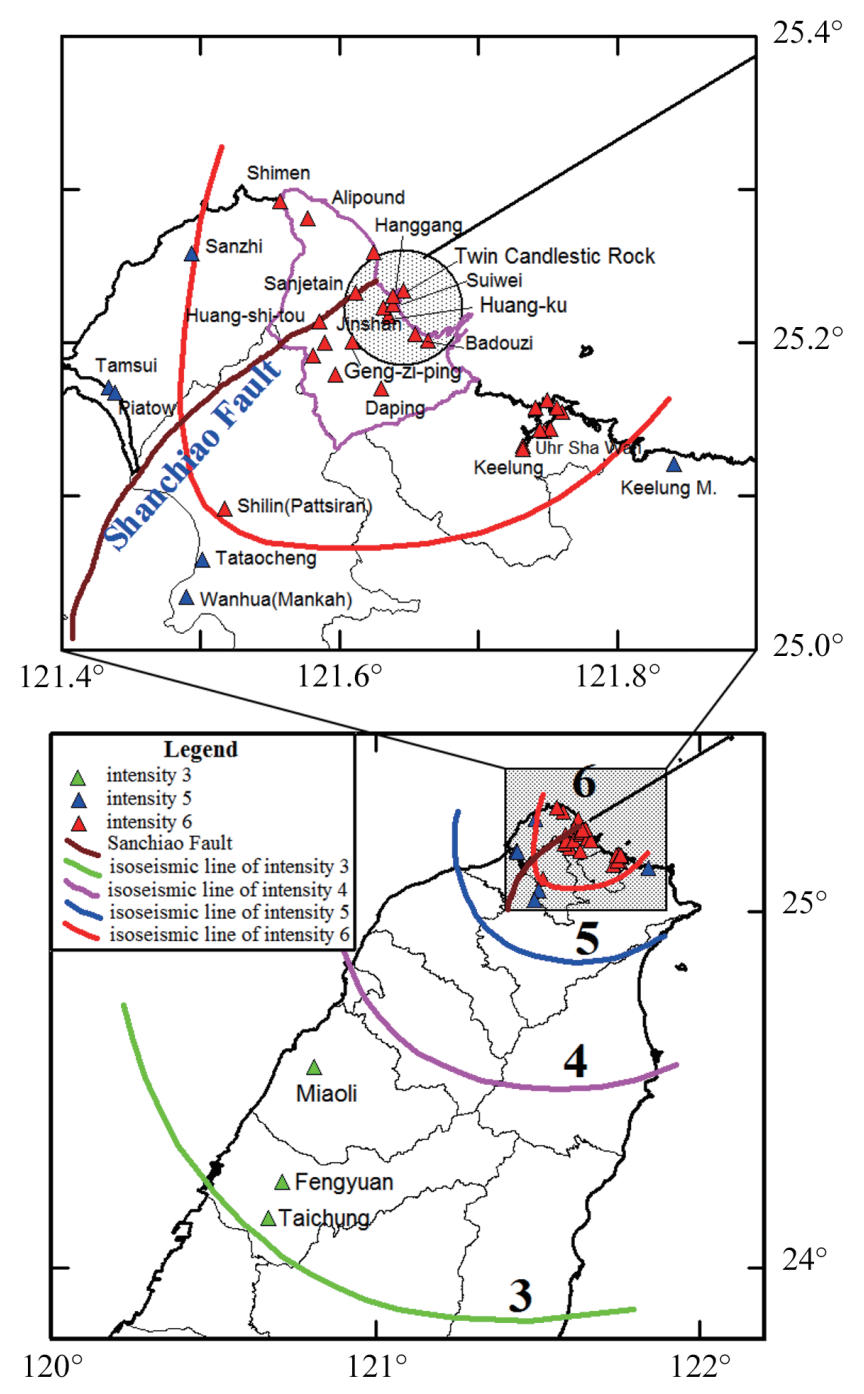

Fig. 3. Intensity distribution and isoseismic map of the 1867 Keelung earthquake. The red, blue, and green triangles represent intensity levels of 6,5 , and 3 . The red, blue, purple, and green lines represent isoseismic lines of levels $6,5,4$, and 3 respectively. (Color online only)

severe landslide occurred between Geng-zi-ping and Huangzuishan. The earthquake caused a landslide of $600-700 \mathrm{~m}$ in length and formed a gorge through which flowed a hot spring stream containing sulfur. The disaster engulfed the whole of Kim-pau-li-po (the enclosed area delineated by the purple line in Fig. 3), killing 400 people which included 70 or 80 people swallowed up by the tsunami while picking up fish during the time the water receded. More than 100 were injured. The earthquake destroyed around 100 and 200 houses were inundated along the coast. Numerous houses were half-collapsed and partially damaged. The earthquake caused one or two houses to catch fire. Buffaloes were left to fend for themselves in pastures during the day time and 30 buffaloes and 300 pigs were crushed to death inside the buildings. There is a lack of statistical disaster reports in the Keelung region; however, it is believed that the damage was less severe than in Jinshan. In Ta-sha-wan and Uhr Sha Wan most of the houses toppled and many people were buried in the debris. The ground cracked in front of the Keelung Customs House in Uhr Sha Wan, which measured at level 6 in intensity. The city of Keelung was smashed badly. However, Qingan Temple and Dodd's home located near the harbor were reported to have been undamaged. The intensity was measured at a level of 6 . Shimen village was considerably damaged, but no one was hurt, again at 6 in intensity. Half of Shilin Old Street (Pa tsien na) was seriously struck and 150 people were killed, which represents a level of 6 in intensity. The major damage in Tamsui occurred on the hill behind the Hobe market. Houses tumbled and many were killed. Thirty deaths were estimated in Tamsui, representing an intensity level of 5. In Piatow the walls of the former British Merchant Warehouse cracked, the roof tiles fell and broke and the mud walls shattered. This damage is rated as level 5 in intensity. In Mankah slight damage was recorded. Mud houses crashed in the suburbs. A big crack appeared on the Mankah Plain. The Tamsui River surface was bubbling like boiling water, with mud and trash on the river bed brought up to the surface, representing an intensity level of 6 . In Tataocheng the earthquake did not cause widespread damage. A two-story building built about 15 or 16 years previously stood firmly after the shock, which measured 5 in intensity. The estimated intensity corresponding to each location shown in Table 6 is labeled in Fig. 3. An isoseismic map is shown illustrating the intensity distribution observed. In the figure the red, blue, purple, and green lines represent isoseismic lines for levels $6,5,4$, and 3 respectively. From the isoseismic map it can be seen that Jinshan was the most seriously affected. Although ground subsidence and cracking occurred in Shanjetain and Huang-shi-tou where the onshore Shanchiao Fault lies, this does not show too many links to the 1867 Keelung earthquake. The subsidence and cracking were more related to the movement effects of the extending parts of the Shanchiao Fault seawards to the north-east. Apart from the damage known for Keelung where it is only known that hundreds were killed and injured, the available documents show that at least 580 were killed, 70 or 80 people were swallowed up by the tsunami in Jinshan and more than 100 were injured. The earthquake demolished around 100 and 200 houses were inundated along the coast. Numerous houses were half collapsed and partially damaged.

Applying the source parameters generated from the simulation of the six models in Table 6 and correlating them with the Intensity Distribution and Isoseismic Map in Fig. 3, the validity and rationality of the source parameters can be examined. With variables of fault length of 30,40 , and $50 \mathrm{~km}$ and rupture types of surface and subsurface with two upper limit depths of 0 and $10 \mathrm{~km}$, six models could be simulated. Based on research by the Central Geological Survey (2007), the marine seismic measurement data show that the dip angle of the offshore extension of the Shanchiao Fault 
is greater than 62 degrees and the direction of the fault is N60E, deduced from the Active Fault Map of Taiwan (2012) (Central Geological Survey 2012). According to the findings of Lee and Wang (1988) that the onshore Shanchiao Fault is a normal fault, this study works on the assumption that the Shanchiao Fault part that extends into the sea in the northeast is also a normal fault and that the rake is $-90^{\circ}$. Six different source model parameters corresponding to the relative intensity and distance from the epicenter are shown in Table 7. Isoseismic maps were drawn with the data generated from Table 7 as shown in Figs. 4, 5, and 6. In Fig. 4 the fault length is $30 \mathrm{~km}$, the epicenter is at $25.31^{\circ} \mathrm{N}, 121.93^{\circ} \mathrm{E}$, and the focal depth is $17 \mathrm{~km}$ which refers to an upper limit depth of $10 \mathrm{~km}$. The moment magnitude $\left(\mathrm{M}_{\mathrm{w}}\right)$ is 6.6 and the

Table 7. The simulated source parameter results from the six models. Jean: The empirical attenuation laws of Jean et al. (2006), Eq. (3). Shin: The empirical attenuation laws of Shin (1998), Eq. (4). Arabic numerals in the table represent the distance calculated from the attenuation laws.

\begin{tabular}{|c|c|c|c|c|c|c|c|}
\hline Mag Intensity & $\begin{array}{c}7 \\
0.4 \mathrm{~g} \\
\end{array}$ & $\begin{array}{c}6 \\
0.25 \mathrm{~g} \\
\end{array}$ & $\begin{array}{c}5 \\
0.08 \mathrm{~g} \\
\end{array}$ & $\begin{array}{c}4 \\
0.025 \mathrm{~g} \\
\end{array}$ & $\begin{array}{c}3 \\
0.008 \mathrm{~g} \\
\end{array}$ & $\begin{array}{c}2 \\
0.0025 \mathrm{~g} \\
\end{array}$ & $\begin{array}{c}1 \\
0.0008 \mathrm{~g} \\
\end{array}$ \\
\hline \multicolumn{8}{|c|}{ Surface fault length $30 \mathrm{~km}$ (upper limit depth $0 \mathrm{~km}$ ) } \\
\hline 6.7 (Jean) & 17.0 & 21.8 & 40.0 & 74.4 & 136.5 & 253.9 & 466.2 \\
\hline 6.7 (Shin) & 7.6 & 14.1 & 37.5 & 79.1 & 150.4 & 277.6 & 495.2 \\
\hline \multicolumn{8}{|c|}{ Surface fault length $40 \mathrm{~km}$ (upper limit depth $0 \mathrm{~km}$ ) } \\
\hline 6.8 (Jean) & 18.2 & 23.4 & 42.9 & 79.7 & 146.4 & 272.3 & 499.9 \\
\hline 6.8 (Shin) & 8.4 & 15.5 & 40.9 & 86.2 & 163.7 & 302.1 & 538.7 \\
\hline \multicolumn{8}{|c|}{ Surface fault length $50 \mathrm{~km}$ (upper limit depth $0 \mathrm{~km}$ ) } \\
\hline 6.9 (Jean) & 19.5 & 25.0 & 46.0 & 85.5 & 157.0 & 292.0 & 536.1 \\
\hline 6.9 (Shin) & 9.3 & 17.0 & 44.6 & 93.9 & 178.2 & 328.7 & 586.0 \\
\hline \multicolumn{8}{|c|}{ Subsurface fault length $30 \mathrm{~km}$ (upper limit depth $10 \mathrm{~km}$ ) } \\
\hline 6.5 (Jean) & 13.9 & 18.3 & 38.4 & 64.5 & 118.6 & 220.7 & 405.4 \\
\hline 6.5 (Shin) & 3.8 & 10.6 & 31.1 & 66.5 & 126.9 & 234.4 & 418.4 \\
\hline \multicolumn{8}{|c|}{ Subsurface fault length 40 km (upper limit depth $10 \mathrm{~km}$ ) } \\
\hline 6.7 (Jean) & 16.2 & 21.2 & 39.7 & 74.2 & 136.4 & 253.8 & 466.2 \\
\hline 6.7 (Shin) & 5.8 & 13.2 & 37.1 & 79.0 & 150.3 & 277.6 & 495.1 \\
\hline \multicolumn{8}{|c|}{ Subsurface fault length $50 \mathrm{~km}$ (upper limit depth $10 \mathrm{~km}$ ) } \\
\hline 6.8 (Jean) & 17.5 & 22.8 & 42.6 & 79.6 & 146.3 & 272.2 & 500.0 \\
\hline 6.8 (Shin) & 6.8 & 14.6 & 40.6 & 86.1 & 163.7 & 302.0 & 538.6 \\
\hline
\end{tabular}
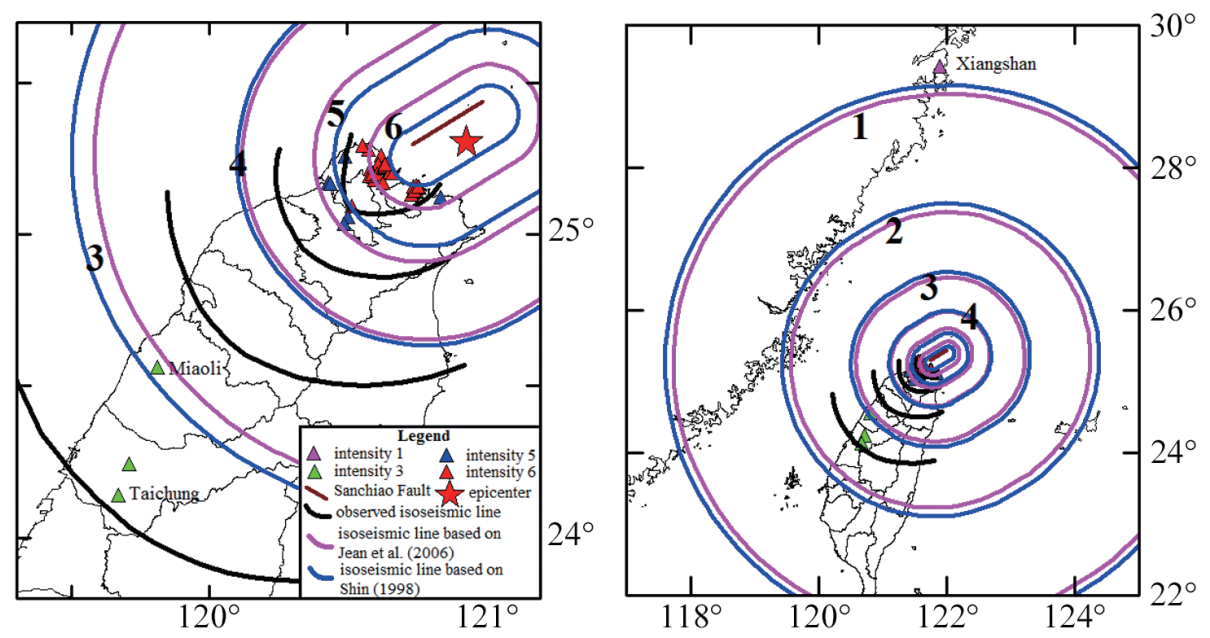

Fig. 4. Comparison of isoseismic map of observation and model result (fault length $30 \mathrm{~km}$, epicenter $25.31^{\circ} \mathrm{N}, 121.93^{\circ} \mathrm{E}, \mathrm{depth}^{17} \mathrm{~km}, \mathrm{M}_{\mathrm{w}} 6.6$, $\mathrm{M}_{\mathrm{L}}$ 6.5). The blue and purple curves are isoseismic lines based on the methods of Shin (1998) and Jean et al. (2006). The bold black lines are observed isoseismic lines. The red star shows the locations of epicenter. (Color online only) 

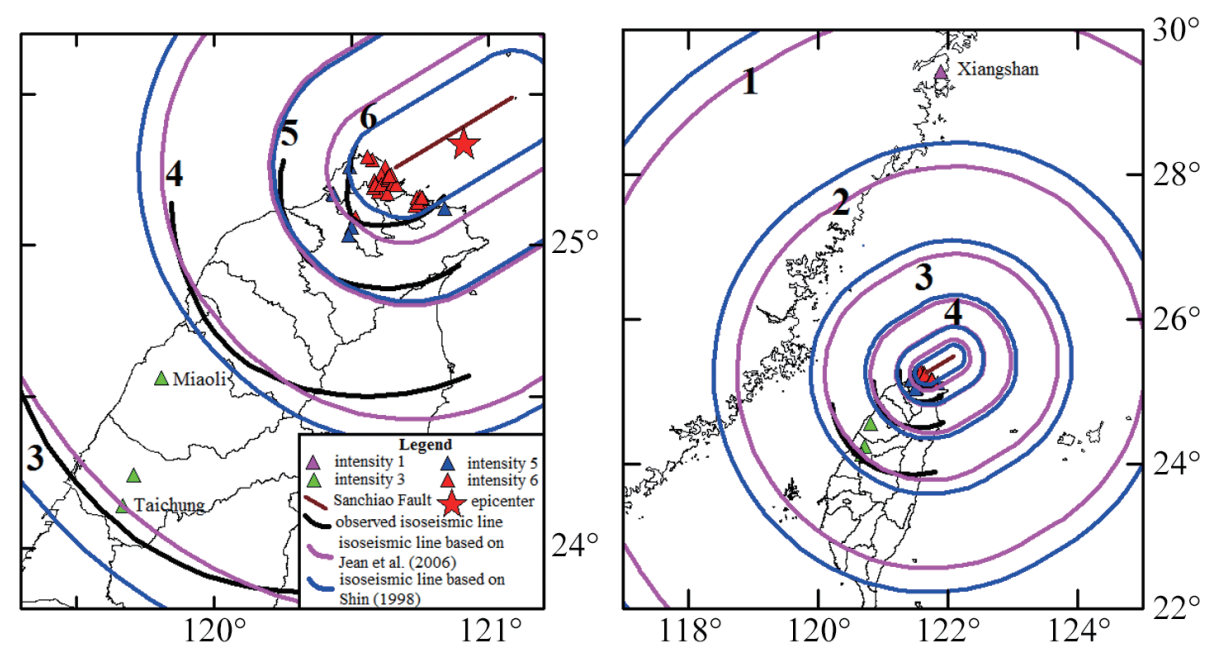

Fig. 5. Comparison of isoseismic map of observation and model result (fault length $50 \mathrm{~km}$, epicenter $25.34^{\circ} \mathrm{N}, 121.91^{\circ} \mathrm{E}, \mathrm{depth}^{\mathrm{s}} 10 \mathrm{~km}, \mathrm{M}_{\mathrm{w}} 7.1, \mathrm{M}_{\mathrm{L}}$ 6.9.). The blue and purple curves are isoseismic lines based on the methods of Shin (1998) and Jean et al. (2006). The bold black lines are observed isoseismic lines. The red star shows the locations of epicenter. (Color online only)
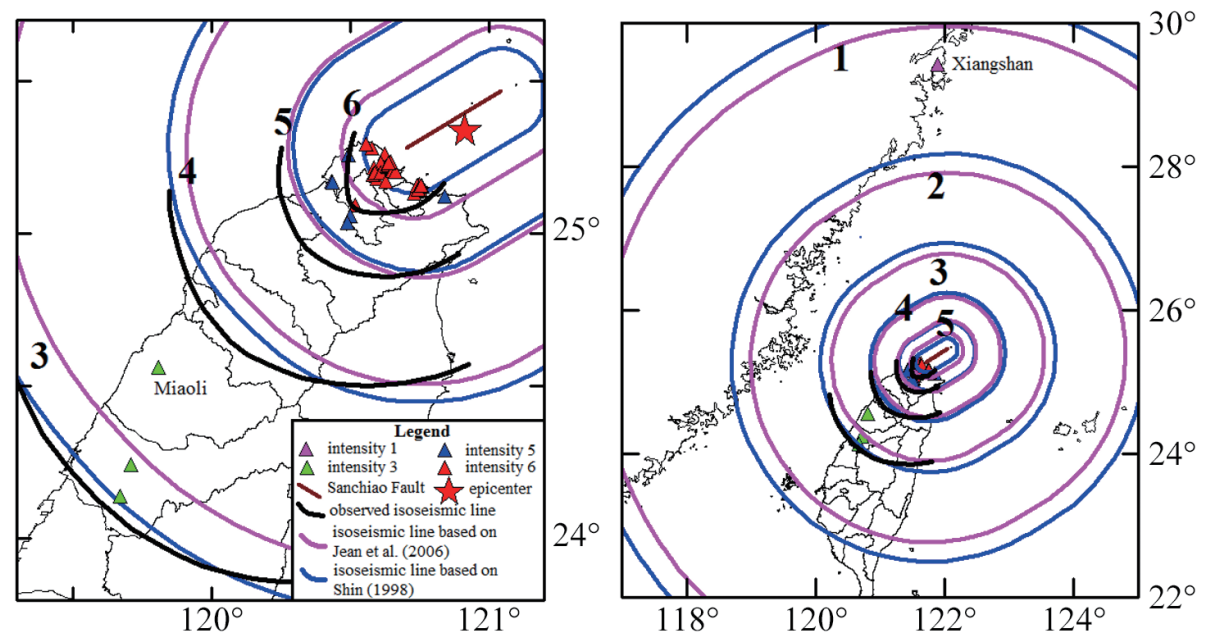

Fig. 6. Comparison of isoseismic map of observation and model result (fault length $40 \mathrm{~km}$, epicenter $25.34^{\circ} \mathrm{N}, 121.91^{\circ} \mathrm{E}, \mathrm{depth}^{\circ} 10 \mathrm{~km}, \mathrm{M}_{\mathrm{w}} 7.0, \mathrm{M}_{\mathrm{L}}$ 6.8.). The blue and purple curves are isoseismic lines based on the methods of Shin (1998) and Jean et al. (2006). The bold black lines are observed isoseismic lines. The red star shows the locations of epicenter. (Color online only)

local magnitude $\left(\mathrm{M}_{\mathrm{L}}\right)$ is 6.5 . The simulation results are not ideal in that they produce insufficient energy released by an earthquake. In Fig. 5 the fault length is $50 \mathrm{~km}$, the epicenter is at $25.34^{\circ} \mathrm{N}, 121.91^{\circ} \mathrm{E}$, and the focal depth is $10 \mathrm{~km}$ which refers to a surface fault. The moment magnitude $\left(\mathrm{M}_{\mathrm{w}}\right)$ is 7.1 and the local magnitude $\left(\mathrm{M}_{\mathrm{L}}\right)$ is 6.9 . The result shows distortion in the high intensity areas which represents too much energy released by an earthquake. In Fig. 6 the fault length is $40 \mathrm{~km}$, the epicenter is at $25.34^{\circ} \mathrm{N}, 121.91^{\circ} \mathrm{E}$, and the focal depth is $10 \mathrm{~km}$ which refers to a surface fault. The moment magnitude $\left(\mathrm{M}_{\mathrm{w}}\right)$ is 7.0 and the local magnitude $\left(\mathrm{M}_{\mathrm{L}}\right)$ is 6.8. The simulation results in an ideal estimated epicenter. Therefore, this study considers the result shown in Fig. 6. When the fault length is $40 \mathrm{~km}$, the focal depth is $10 \mathrm{~km}$ and the strike, dip and rake of the possible plane are N60E, 62 and -90 respectively, the epicenter is at $25.34^{\circ} \mathrm{N}, 121.91^{\circ} \mathrm{E}$, the depth is $10 \mathrm{~km}$, the moment magnitude $\left(\mathrm{M}_{\mathrm{w}}\right)$ is 7.0 , and the local magnitude $\left(\mathrm{M}_{\mathrm{L}}\right)$ is 6.8 , an ideal result. The issue about the possibility for a normal fault with a length of $40 \mathrm{~km}$ and a moment magnitude $\left(\mathrm{M}_{\mathrm{w}}\right)$ of 7.0 producing a wave height of $6 \mathrm{~m}$ and whether the tsunami was intensified by underwater landslides caused by the earthquake will not be discussed here. Our study focuses on reconstructing the damage distribution, run-up height and wave height of the tsunami.

\section{CONCLUSION}

This study reviewed the correlative historical literature 
and documents about the 1867 Keelung earthquake and tsunami. Seventy-six historical documents were sorted, comprising twenty local versions from the literature (Table 1), 45 personal records and articles (Table 2) and 11 temple establishment histories and epigraphs. However, documents from official records are still missing and efforts will be made to find them in the future. These original data and files will be input to the website: The Data-Base of Historical Earthquake Documents in Taiwan (http://tc.earth.sinica. edu.tw/TEM/hisevent/hisdoc.php) to enrich the integrity of the database and to provide references for further study.

After collecting and collating the documents, analyzing the data reliability and verifying the names in literature, the Central Weather Bureau Intensity Scale was used to correlate the damage distribution at the time using the present-day map to show the damage spatial distribution. We also developed the most likely isoseismic map for the earthquake and reconstructed the damage resulting from the subsequent tsunami. The isoseismic map indicates that the 1867 Keelung earthquake was correlated highly with the northeast offshore extension of the Shanchiao Fault. Excluding the damage record from the Keelung Harbor area, the 1867 Keelung earthquake and tsunami killed more than 580 people. Jinshan was the worst damaged region. With a recorded observed wave height of $6 \mathrm{~m}$ in Huangkang and Shueiwei, Jinbaoli Old Street and Badouzi were inundated (which is where the second nuclear power plant is located at present) by the tsunami run-up of up to $15 \mathrm{~m}$ in height. The tsunami wave height was observed to have been $205 \mathrm{~cm}$ high in Keelung Harbor Bay. The tsunami smashed Tongpan Islet, Heping Island, Ta-sha-wan and Uhr Sha Wan east of the harbor, and downtown Keelung. The damage situation in Keelung City was slight and only occurred on the low-lying land along the coast. The areas along the coast from Jinshan to Keelung Harbor are also inferred to have been major effected areas.

Using the attenuation law, the simulated isoseismic map was compared with the corresponding disaster distribution to estimate more reasonable source parameters. The results show that the 1867 Keelung earthquake was correlated highly with parts of the Shanchiao Fault extending into the sea to the north-east. When the strike, dip and rake of the possible plane are $\mathrm{N} 60 \mathrm{E}, 62$, and -90 respectively, it can be inferred that the epicenter is $25.34^{\circ} \mathrm{N}, 121.91^{\circ} \mathrm{E}$, the depth was $10 \mathrm{~km}$, the moment magnitude $\left(\mathrm{M}_{\mathrm{w}}\right)$ was 7.0 , and the local magnitude $\left(\mathrm{M}_{\mathrm{L}}\right)$ was 6.8 .

Acknowledgements We are deeply grateful to the three Anonymous Reviewers for critical comments and wise suggestions on this paper. This work was supported by the Ministry of Science and Technology (grant number MOST 1042116-M-231-001 and MOST 104-2119-M-006-007). Our thanks to Keelung City Government, Z. Y. Chen, Section Chief of Fire Department, Z. X. Lin, Director of Mortuary
Service Office, Y. H. Zhuang, Assist Manager of the Port of Keelung Taiwan International Ports Corporation, LTD., Dr. K. C. Chen at Institute of Earth Sciences of Academia Sinica, Dr. C. H. Chang at Seismological Center of Central Weather Bureau, and Dr. G. F. Ma at Department of Earth Sciences of National Central University for their help with collecting and compiling documents and providing helpful suggestions.

\section{REFERENCES}

Abe, A., 1938: The Study of Local Name in Taiwan, Shigeru-go Research Club, 355 pp. (in Japanese)

Alvarez, J. M., 1915: Descripcion Geografica de la isla de Formosa, Madrid Imprenta del Patronato de Huerfanos de Intendencia e Intervencion Militares, 615 pp. (in Spanish)

Central Geological Survey, 2007: Fugueijiao offshore. Geological Map of the Ocean, ROC, Central Geological Survey, MOEA, 37 pp. (in Chinese)

Central Geological Survey, 2012: Taiwan Active Fault (2012),Central Geological Survey, MOEA. Available at http://fault.moeacgs.gov.tw/TaiwanFaults_2009/ PageContent.aspx?type $=\mathrm{C} \& \mathrm{id}=5$.

Chen, P. G., 1871: The History of the Tamsui Prefecture, Economic Research of Taiwan Bank, Taiwan Series Literature No. 124, Taiwan Bank. (in Chinese)

Cheng, S. N., 2014a: The data-base of historical earthquake documents in Taiwan. Ti-Chih, 33, 22-27. (in Chinese)

Cheng, S. N., 2014b: The disaster of the 1867 Keelung Earthquake and Tsunami, based on historical document. Ti-Chih, 33, 36-39. (in Chinese)

Cheng, S. N. and Y. T. Yeh, 1989: Catalog of the earthquakes in Taiwan from 1604 to 1988. Open File Report, Institute of Earth Sciences, Academia Sinica, 255 pp. (in Chinese)

Davidson, J. W., 1903: The Island of Formosa, Past and Present, Macmillan \& Co., Kelly \& Walsh, Ltd., London and New York.

Dodd, J., 1888: Journal of a Blockaded Resident in North Formosa during the Franco-Chinese War, 1884-5, Hong Kong, 229 pp.

Fang, H., 1969: A Compilation of Historical Records of Taiwan Earthquake before the Twentieth Century, Selection of Own Writings on Sixtieth Birthday, 693-737. (in Chinese)

Garnot, E. G., 1884: L'expédition Française de Formose, 1884-1885, Paris: Librairie Ch. Delagrave. (in French)

Hancock, W., 1882: Tamsui trade report, for the year 1881 . Reports on Trade at the Treaty Ports for the Year 1881, Shanghai: Statistical Department of the Inspectorate General of the Imperial Maritime Customs, 1-38.

Heck, N. H., 1947: List of seismic sea waves. Bull. Seismol. 
Soc. Am., 37, 269-286.

Holt, H. F., 1868: Report of recent earthquakes in northern Formosa. Q. J. Geol. Soc., 24, 510, doi: 10.1144/GSL. JGS.1868.024.01-02.62. [Link]

Hsu, H., 1983a: A collection of historical materials of Taiwan natural disasters in Qing Era. Disaster Prevention Research Report 72-01, National Science Council, 114 pp. (in Chinese)

Hsu, M. K. and Q. Li, 1996: Tsunami in the region near Taiwan. Acta Oceanogr. Taiwan., 35, 1-16. (in Chinese)

Hsu, M. T., 1966: Seismicity of Taiwan. Meteorol. Bull., 12, 33-51.

Hsu, M. T., 1971: Seismicity of Taiwan and some related problems. Bull. Intern. Inst. Seis. Earthq. Eng., 8, 41-160.

Hsu, M. T., 1981: Tsunamis and their damages. Meteorol. Bull., 27, 1-15. (in Chinese)

Hsu, M. T., 1983b: Estimation of earthquake magnitudes and seismic intensities of destructive earthquakes in the Ming and Ching Eras. Meteorol. Bull., 29, 1-18. (in Chinese)

Hsu, T. L., 1955: The earthquakes of Taiwan. Quart. J. Bank Taiwan, 7, 148-164. (in Chinese)

Iida, K., 1984: Catalog of tsunamis in Japan and its neighboring countries. Special Report, December 1984, Aichi Institute of Technology, Japan. (in Japanese)

Iida, K., D. C. Cox, and G. Pararas-Carayannis, 1967: Preliminary Catalog of Tsunamis Occurring in the Pacific Ocean. Data Report No. 5, Hawaii Inst. of Geophysics Honolulu, Hawaii.

Institute of Geology, State Seismological Bureau, 1979: Summary Instruction on the Seismotectonic Map of People's Republic of China, with a Brief Catalogue of Stronger Quakes in China, Cartographic Publishing House, 36 pp. (in Chinese)

Jane, W. H., 1931: Chronicles of Keelung, Keelung Book Publishers Association, 189 pp. (in Japanese)

Jean, W. Y., Y. W. Chang, K. L. Wen, and C. H. Loh, 2006: Early estimation of seismic hazard for strong earthquakes in Taiwan. Nat. Hazards, 37, 39-53, doi: 10.1007/s11069-005-4655-y. [Link]

Jhuang, J. M., K. S. Shieh, J. H.Zang, S. O. Bao, S. T. Lu, H. T. Chu, Y. C. Liu, Y. H. Lin, P. T. Chen, C. Y. Huang, and Y. L. Jiang, 2012: Preliminary study of the Tsunami deposits in archeological trench, Heping Island, Keelung. 100 Annual Business Results Presentation Manual, Central Geological Survey, MOEA, p. 28.

Lee, C. T. and Y. Wang, 1988: Quaternary stress changes in northern Taiwan and their tectonic implication. Proc. Geol. Soc. China, 31, 154-168.

Lee, W. H. K., F. T. Wu, and C. Jacobsen, 1976: A catalog of historical earthquakes in China compiled from recent Chinese publications. Bull. Seismol. Soc. Am., 66, 2003-2016.
Lian, H., 1918: Taiwan T'ung-shih (General History of Taiwan), Economic Research of Taiwan Bank, Taiwan Series Literature No. 128, Taiwan Bank. (in Chinese)

Ma, K. F. and M. F. Lee, 1997: Simulation of historical tsunamis in the Taiwan region. Terr. Atmos. Ocean. Sci., 8, 13-30.

Mackay, G. L., 1896: From Far Formosa: The Island, its People and Missions, Edinburgh: Oliphant Anderson and Ferrier, edited by J. A. MacDonald, F.H. Reell Co., New York, Toronto, 346 pp

Marine Meteorology Center, 2013: Tide Table 2014, Central Weather Bureau, ISSN:1812-1535.

Milne, J., 1912: A Catalogue of Destructive Earthquakes, A.D. 7 to A.D. 1899, The Association, London, 92 pp.

Miyabe, N., 1936: Recent seismic activity in Taiwan. Bull. Earthq. Res. Inst. Tokyo Imperial Univ., 3, 1-9. (in Japanese)

Murakami, T., 1899: Taiwan Bulletin, Police Eye Inc., Tokyo, 340 pp. (in Japanese)

Nishimura, T., 1936: The history of Taiwan earthquake. The 1935 Taiwan Earthquake, Taiwan Government, 121-142. (in Japanese)

Oka, F. B., 1948: A Complete Collection of Taiwan Meteorological Data, Earthquake, Taiwan Weather Bureau, 236 pp. (in Chinese) (unpublished)

Okamoto, Y., 1913: Terrain changes around Jinbaoli during Tongzhi years. Trans. Nat. History Soc. Formosa, 3, 168-169. (in Japanese)

Omori, F., 1906: Investigation of Taiwan earthquake. Report of Imp. Earthquake Invest. Comm., No. 54, 1-223. (in Japanese)

Omori, F., 1907: Preliminary note on the Formosa Earthquake of March 17, 1906. Bull. Imp. Earthq. Invest. Comm., 1, 53-69.

Omori, F., 1919: Japan big earthquake overview table. Report of Imp. Earthquake Invest. Comm., No. 88(B), 1-71. (in Japanese)

Oyama, I. T., 1934: Taiwan earthquake and intensity. Taiwan Soc. Architecture, 6, 45-65. (in Japanese)

Perrey, A., 1872: Note sur les tremblements de terre en 1868, avec suppléments pour les années antérieures, de 1843 à 1867. Mémoires Couronnés et Autres Mémoires, Vol. 22, 1-116. (in French)

Perrey,A., 1873: Suppléments aux notes sur les tremblements de terre ressentis de 1843 à 1868. Mémoires Couronnés et Autres Mémoires, Vol.23, 1-70. (in French)

Shen, M. Y., 1893: History of the Miaoli Prefecture. Economic Research of Taiwan Bank, Taiwan Series literature No. 159, Taiwan Bank. (in Chinese)

Sheng, C. G., 1971: The relief business of Taiwan disasters in Qing Era. Taiwan Literature, 22, 123-143. (in Chinese)

Shin, T. C., 1998: A preliminary study of the earthquake early warning system in the Taiwan area. Meteorol. Bull., 42, 118-134. (in Chinese) 
Soloviev, S. L. and C. N. Go, 1974: A catalogue of tsunamis on the western shore of the Pacific Ocean (1731968). Nauka Publishing House, Moscow, USSR, Can. Transi. Fish. Aquat. Sci. 5077, 1984, 310 pp.

Su, C. H. and C. T. Lee, 2014: Oceanographical Observation Data--Annual Report 2012 (Tide), Institute of Transportation, Ministry of Transportation and Communications, ISBN 978-986-04-1003-7. (in Chinese)

Taihoku Meteorological Observatory, 1899: Taiwan Meteorological Report, No. 1,90 pp. (in Japanese)

Taihoku Meteorological Observatory, 1914: The Climate, Typhoons, and Earthquakes of the Island of Formosa (Taiwan), Taipei, $80 \mathrm{pp}$.

Taiwan Governor-General Office of Civil Affairs, 1907: Report of Earthquake Damages of Chiayi, Taipei, 428 pp. (in Japanese)

Taiwan Governor Production Bureau of Civil Affairs, 1912: Report of Geological Survey about Datun Volcano, 102 pp. (in Japanese)

Tang, F. L. W., 1971: Planning and design of coastal engineering. Joint Commission on Rural Reconstruction, Special Issue, 2, 1- 475. (in Chinese)

Temporary Taiwan Land Investigation Bureau, 1904: Taiwan Fort Map: 1/20,000 Topographic Map, Yuan-Liou Bublishing Company 1996 Copy Version.

North China Herald and Market Report, 1868: Tamsui, fourth edition, Jan. 8, 1868.

Tsai, Y. B., 1985: A study of disastrous earthquakes in Taiwan, 1683-1895. Bull. Inst. Earth Sci., 5, 1-44.

United Daily News, 1960: Chile Earthquake Caused Tsu- nami, third edition, May 25, 1960. Available at http:// udndata.com/library/.

Wells, D. L. and K. J. Coppersmith, 1994: New empirical relationships among magnitude, rupture length, rupture width, rupture area, and surface displacement. Bull. Seismol. Soc. Am., 84, 974-1002.

$\mathrm{Wu}, \mathrm{T} . \mathrm{R} ., 2013$ : The records of 11 historical tsunamis in Taiwan since 1661. Tsunami Science Research Laboratory, Graduate Institute of Hydrological \& Oceanic Sciences, NCU. Available at http://tsunami.ihs.ncu. edu.tw/tsunami/history.htm.

Xie, Y. and M. Cai, 1987: Compilation of Historical Earthquake Data in China, Vol. 3, The China Seismological Historical Information Editorial Board Editorial Department, Science Press, Peking, 257 pp. (in Chinese)

Xu, N., 1933: A Collection of Xu Nan Ying, Peking, 250 pp. (in Chinese)

Yang, C. S., F. L. W. Tang, and J. L. Shaw, 1983: Mathematical model for calculation of tsunami propagation and tsunami run-up in the northeastern area of Taiwan. Disaster Prevention Research Report 72-23, National Science Council, 57 pp. (in Chinese)

Yoshida, T., 1909: Dainippon Dictionary of Place Name Sequel, Toyamabo Issue, Tokyo. (in Japanese)

Yoshida, T., 1923: Dainippon Dictionary of Place Name, volume VI (Hokkaido, Sakhalin, Ryukyu, Taiwan), Toyamabo Issue, Tokyo. (in Japanese)

Yoshida, T., 1970: Dainippon Dictionary of Place Name, Enlarged Edition. Hokkaido, Sakhalin, Ryukyu, Taiwan, Toyamabo Issue, Tokyo. (in Japanese) 